\title{
Gene expression patterns of red sea urchins (Mesocentrotus franciscanus) exposed to different combinations of temperature and $p \mathrm{CO}_{2}$ during early development
}

\author{
Juliet M. Wong ${ }^{1,2^{*}}$ id and Gretchen E. Hofmann ${ }^{1}$
}

\begin{abstract}
Background: The red sea urchin Mesocentrotus franciscanus is an ecologically important kelp forest herbivore and an economically valuable wild fishery species. To examine how $M$. franciscanus responds to its environment on a molecular level, differences in gene expression patterns were observed in embryos raised under combinations of two temperatures $\left(13^{\circ} \mathrm{C}\right.$ or $17^{\circ} \mathrm{C}$ ) and two $p \mathrm{CO}_{2}$ levels ( $475 \mu \mathrm{\mu tm}$ or $\left.1050 \mu \mathrm{atm}\right)$. These combinations mimic various present-day conditions measured during and between upwelling events in the highly dynamic California Current System with the exception of the $17^{\circ} \mathrm{C}$ and $1050 \mu$ atm combination, which does not currently occur. However, as ocean warming and acidification continues, warmer temperatures and higher $p \mathrm{CO}_{2}$ conditions are expected to increase in frequency and to occur simultaneously. The transcriptomic responses of the embryos were assessed at two developmental stages (gastrula and prism) in light of previously described plasticity in body size and thermotolerance under these temperature and $p \mathrm{CO}_{2}$ treatments.

Results: Although transcriptomic patterns primarily varied by developmental stage, there were pronounced differences in gene expression as a result of the treatment conditions. Temperature and $p \mathrm{CO}_{2}$ treatments led to the differential expression of genes related to the cellular stress response, transmembrane transport, metabolic processes, and the regulation of gene expression. At each developmental stage, temperature contributed significantly to the observed variance in gene expression, which was also correlated to the phenotypic attributes of the embryos. On the other hand, the transcriptomic response to $\mathrm{pCO}_{2}$ was relatively muted, particularly at the prism stage.

(Continued on next page)
\end{abstract}

\footnotetext{
* Correspondence: juliwong@fiu.edu

'Department of Ecology, Evolution and Marine Biology, University of

California Santa Barbara, Santa Barbara, CA 93106, USA

${ }^{2}$ Present address: Department of Biological Sciences, Florida International

University, North Miami, FL 33181, USA
}

(c) The Author(s). 2021 Open Access This article is licensed under a Creative Commons Attribution 4.0 International License, which permits use, sharing, adaptation, distribution and reproduction in any medium or format, as long as you give appropriate credit to the original author(s) and the source, provide a link to the Creative Commons licence, and indicate if changes were made. The images or other third party material in this article are included in the article's Creative Commons licence, unless indicated otherwise in a credit line to the material. If material is not included in the article's Creative Commons licence and your intended use is not permitted by statutory regulation or exceeds the permitted use, you will need to obtain permission directly from the copyright holder. To view a copy of this licence, visit http://creativecommons.org/licenses/by/4.0/ The Creative Commons Public Domain Dedication waiver (http://creativecommons.org/publicdomain/zero/1.0/) applies to the data made available in this article, unless otherwise stated in a credit line to the data. 
(Continued from previous page)

Conclusions: $M$. franciscanus exhibited transcriptomic plasticity under different temperatures, indicating their capacity for a molecular-level response that may facilitate red sea urchins facing ocean warming as climate change continues. In contrast, the lack of a robust transcriptomic response, in combination with observations of decreased body size, under elevated $\mathrm{pCO}_{2}$ levels suggest that this species may be negatively affected by ocean acidification. High present-day $\mathrm{pCO}_{2}$ conditions that occur due to coastal upwelling may already be influencing populations of M. franciscanus.

Keywords: Red sea urchin, Mesocentrotus franciscanus, RNA-seq, Transcriptomics, Early development, Climate change, Warming, Ocean acidification

\section{Background}

The red sea urchin Mesocentrotus franciscanus (A. Agassiz, 1863) is an ecologically and economically valuable species found along the Pacific Coast of western North America [1]. In subtidal areas, especially within kelp forests, these echinoderms are herbivorous ecosystem engineers that can shape the flow of resources within marine habitats [2]. Overgrazing by $M$. franciscanus, often in combination with overgrazing by the purple sea urchin Strongylocentrotus purpuratus, can lead to the formation of urchin barrens in which macroalgal communities are severely reduced or depleted [3, 4]. Red sea urchins also function as prey to animals at higher trophic levels, including spiny lobsters and sea otters [5-7]. In addition to its removal by natural predators, $M$. franciscanus is widely collected as a lucrative wild fishery species. Fisheries in Mexico, the United States, and Canada harvest M. franciscanus for their gonads (i.e., roe) that supply domestic markets as well as international exports, principally to Japan [8, 9]. Over recent years (2015-2019), the annual revenue reported from $M$. franciscanus fisheries across the states of California, Oregon, and Washington averaged over \$7.1 million USD/year, far more than all other echinoderm fishery species combined [10].

Given the considerable ecological and economic importance of $M$. franciscanus, determining how this species will be affected by continuing environmental change in coastal oceans remains an overlooked and critical area of research [11]. Due to their habitat and life history, these urchins are threatened by climate change impacts [12] such as ocean warming, which may include sudden and extreme marine heat waves $[13,14]$, and ocean acidification, which may amplify the low $\mathrm{pH}$ conditions that episodically occur in upwelling regions [15]. The upwelling season in the California Current System (CCS) typically extends from early spring until late summer or fall; it is characterized by fluctuations between periods of upwelling, when cold, low $\mathrm{pH}$ water is transported to the surface, and periods in which upwelling is relaxed (i.e., wind conditions are not conducive for driving upwelling) $[16,17]$. This overlaps with the natural spawning period of $M$. franciscanus that occurs annually during spring and early summer months [18-20]. Therefore, in the CCS, M. franciscanus embryos and larvae experience combinations of temperature and $\mathrm{pH}$ conditions that may vary depending on whether spawning and upwelling events coincide. Furthermore, these urchins may be particularly vulnerable to stress during early development. Although planktonic embryological and larval stages of echinoids are capable of exhibiting vertical migration $[21,22]$, they are likely less capable of finding refuge from stressful conditions than their benthic adult counterparts. There is also evidence that many organisms are most vulnerable to environmental stress early in their life history [23-26]. Both lethal and sublethal effects that occur during early development or that carry over into later life stages will negatively affect the recruitment necessary to support future populations [27, 28].

Given the dynamic nature of their habitat and the progression of ocean warming and acidification, it is imperative to understand how early stage $M$. franciscanus respond to their environment on a molecular level. A limited number of studies have investigated how $M$. franciscanus responds to temperature or $p \mathrm{CO}_{2}$ stress [29-31], and even fewer have done so within a multistressor context [32]. In S. purpuratus, a species whose habitat largely overlaps with that of $M$. franciscanus, elevated temperatures and $p \mathrm{CO}_{2}$ levels during early development can cause increased mortality, abnormality, and a reduction in size and scope for growth [20, 3335]. Several studies have identified and examined temperature- and $p \mathrm{CO}_{2}$-responsive genes in $S$. purpuratus embryos and larvae [36-41]. Studies such as these are essential for contributing molecular-level insights into how these organisms respond, or fail to respond, to stressful environmental conditions and may help explain effects observed at the level of the organism or population. This is particularly pertinent for fishery species in which accurate predictions are necessary for adaptive, climate-ready fisheries management [42]. Although a clear understanding of how $M$. franciscanus responds to environmental stress is lacking, suggestions have already been made to replace or offset the $M$. franciscanus fishery with Strongylocentrotus fragilis, a sea urchin species 
expected to be more tolerant to climate change [12]. Here, both temperature and $p \mathrm{CO}_{2}$ conditions were manipulated in a laboratory setting to investigate their influence on the gene expression patterns of $M$. franciscanus during its early development. To the best of our knowledge, this is the first study to use RNA sequencing (RNA-seq) to examine the $M$. franciscanus stress response.

In this study, $M$. franciscanus embryos were raised under a combination of two temperatures $\left(13{ }^{\circ} \mathrm{C}\right.$ or $17^{\circ} \mathrm{C}$ ) and two $p \mathrm{CO}_{2}$ levels $(475 \mu \mathrm{atm}$ or $1050 \mu \mathrm{atm})$ that reflect current and future ocean conditions in their natural habitat [15, 43-45]. This generated four different treatment combinations: 1) $17^{\circ} \mathrm{C}$ and $1050 \mu \mathrm{atm} p \mathrm{CO}_{2}$, 2) $17^{\circ} \mathrm{C}$ and $\left.475 \mu \mathrm{atm} p \mathrm{CO}_{2}, 3\right) 13{ }^{\circ} \mathrm{C}$ and $1050 \mu \mathrm{atm}$ $p \mathrm{CO}_{2}$, and 4) $13^{\circ} \mathrm{C}$ and $475 \mu$ atm $p \mathrm{CO}_{2}$. In the highly dynamic CCS, treatment combinations \#2-4 are currently measured during and between upwelling events [15, 43-45]. Future ocean conditions are represented by treatment combination \#1 (i.e., the simultaneous occurrence of $17^{\circ} \mathrm{C}$ and $1050 \mu \mathrm{atm} p \mathrm{CO}_{2}$ ) given continued ocean warming and acidification. Additional detail regarding the selection of these temperature and $p \mathrm{CO}_{2}$ treatment levels is located in the Methods. Gene expression patterns were assessed at both the gastrula and prism embryo stages. We also discuss the gene expression results within the context of previously reported physiological assessments from this experiment, including body size and thermotolerance [46]. Here, we describe the effects of the temperature and $p \mathrm{CO}_{2}$ treatments at the molecular level and whether they relate to observations made at the level of the organism.

Temperature elicited a robust transcriptomic response at both developmental stages. Gene expression analyses indicated that the warmer temperature (i.e., $17^{\circ} \mathrm{C}$ ) induced a cellular stress response, amongst other processes. Additionally, the variation in gene expression that was significantly correlated to the temperature treatment was also significantly correlated to embryo body size and thermotolerance, characteristics that were neutrally or positively influenced by the warmer temperature treatment [46]. In contrast, the transcriptomic response to the $p \mathrm{CO}_{2}$ treatment was comparatively muted. This minor molecular-level response may explain the reduction in embryo body size that is observed under elevated $p \mathrm{CO}_{2}$ levels (i.e., $1050 \mu \mathrm{atm}$ ) [46]. Overall, we examined a valuable fishery species that is capable of dramatically shaping coastal ecosystems, and determined that during early development $M$. franciscanus exhibits different magnitudes of transcriptomic plasticity in response to two climate change-related stressors. This study provides much needed insight into a species that is important for many fisheries on the Pacific coast of North America, facilitating our understanding of how $M$. franciscanus development is affected by current ocean conditions, as well as our predictive capacity of how this species will respond to future ocean change.

\section{Results}

\section{Summary statistics and overview of RNA-seq}

The samples used for RNA-seq were generated from triplicate cultures of embryos raised at each of the four combined temperature and $p \mathrm{CO}_{2}$ treatments (i.e., 12 total cultures) (see Additional file 1). Each sample was collected as a pool of 5000 embryos from each of the 12 cultures at both the gastrula and prism stages during development to produce a total of 24 samples used for RNA extractions and library preparation. Sequencing of the 24 libraries yielded a total of 728,782,735,100-bp single reads. After quality trimming, an average of $30.3 \pm$ 1.3 million reads per library remained. FASTQC reports [47] of trimmed sequences showed high sequence quality (>30) with limited adapter contamination or presence of overrepresented sequences. Per-library mapping efficiency to the developmental transcriptome [48] using RSEM [49] was at an average of 52.6\%. The presence of mitochondrial rRNA appeared to have contributed to the percentage of unmapped reads, although mapping rate may have also been affected by the completeness of the reference transcriptome.

\section{Developmental stage influenced transcriptomic patterns}

A principal component analysis (PCA) of sample-tosample distances showed that differences in gene expression profiles were primarily between the two developmental stages, gastrula and prism (Fig. 1a). Principal Component (PC) 1 captured the majority of the variance $(67.5 \%)$ and revealed a clear separation between gastrula and prism stage embryos, while PC2 only captured 3.8\% of the variance. Indeed, a permutational multivariate ANOVA across all 24 samples with developmental stage, temperature treatment, and $p \mathrm{CO}_{2}$ treatment as fixed factors, revealed that developmental stage explained $66.4 \%$ of the variance $(p=0.001)$ (Fig. 1b). In contrast, temperature treatment explained only $4.1 \%$ of the variance $(p=0.041)$ and $p \mathrm{CO}_{2}$ treatment explained only $2.3 \%$ of the variance $(p=0.207)$. All factor interactions were not significant $(p>0.05)$. Results from gene expression analyses across all samples independent of stage (i.e., gastrula and prism stages were not analyzed separately) are available in Additional file 2 . Because we have previously explored the differences in gene expression patterns across $M$. franciscanus during early development [48] and it is not the main focus of the current study, from here onward we report separate gene expression analyses for the gastrula and prism stages. 

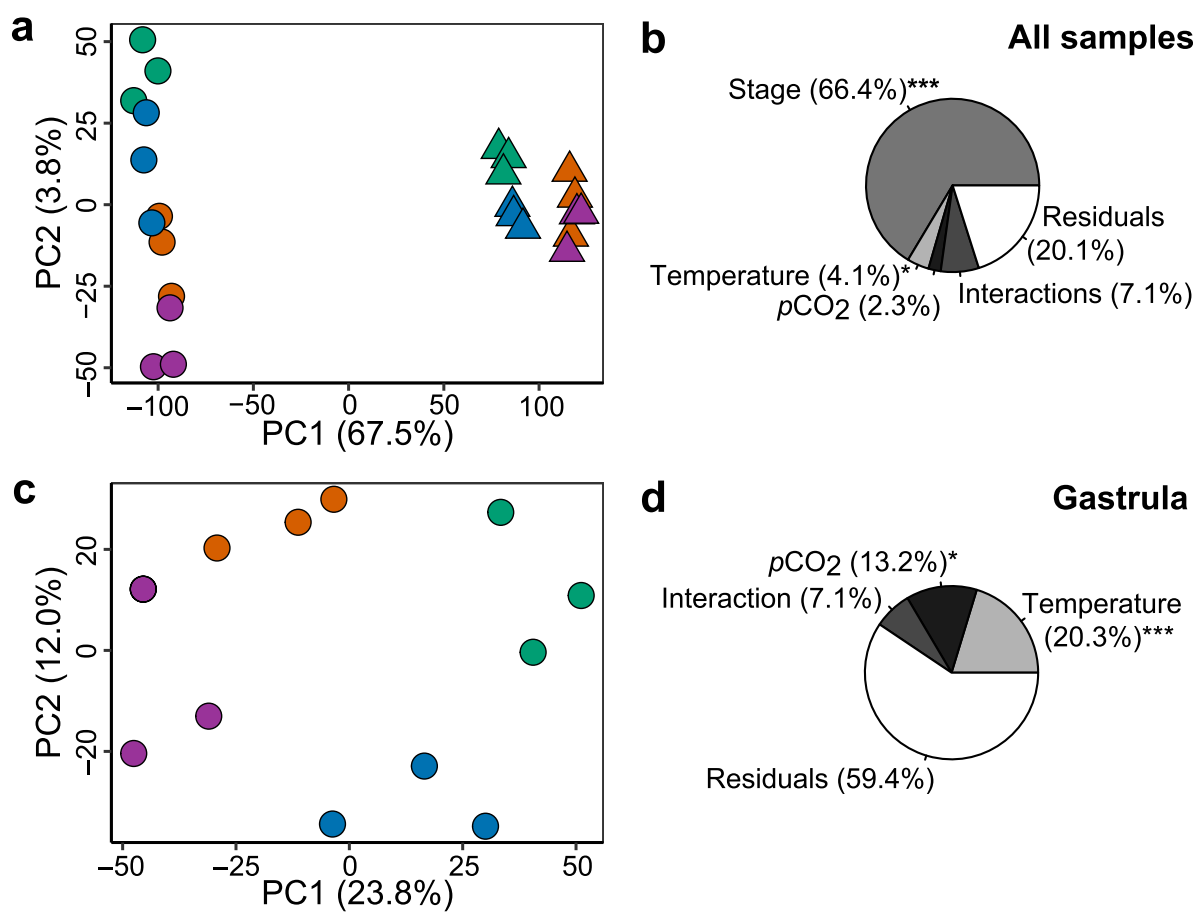

d

Gastrula

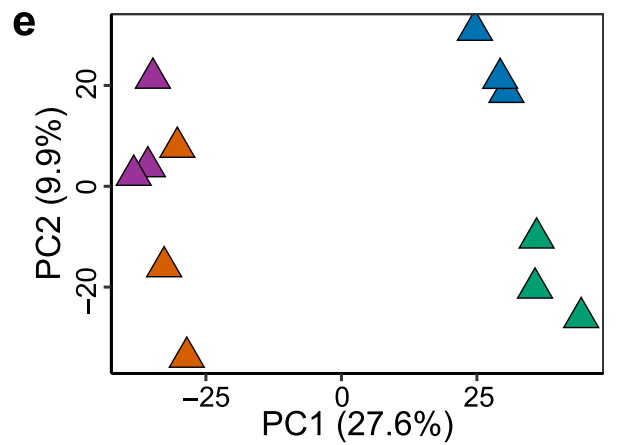

f

Prism

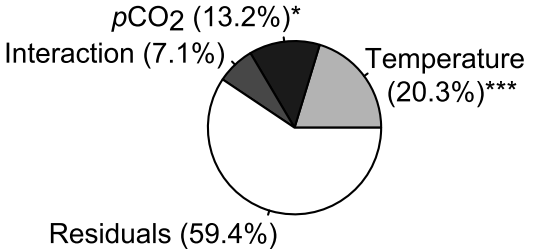

Residuals $(59.4 \%)$
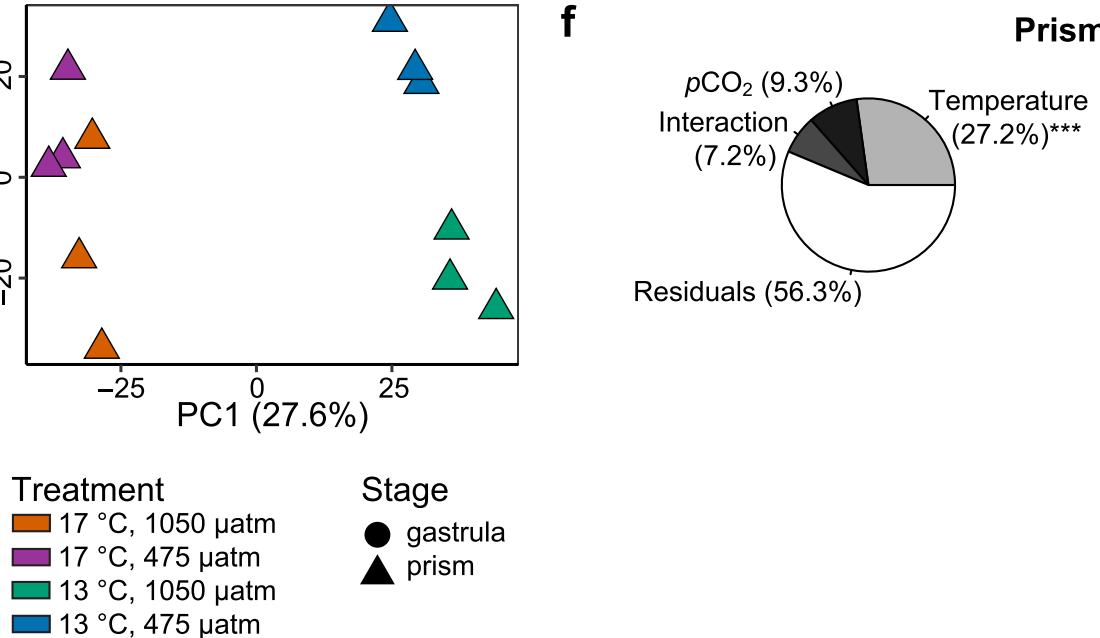

Fig. 1 General gene expression patterns. Principal component analysis (PCA) plots of $\mathbf{a}$ all samples, $\mathbf{c}$ the gastrula stage only, and $\mathbf{e}$ the prism stage only are displayed with the two components that explained the most variance. Pie charts $(\mathbf{b}, \mathbf{d}$, and $\mathbf{f})$ display the percent of variation explained by fixed factors determined using permutational multivariate ANOVAs $\left({ }^{*} p<0.05\right.$ and $\left.{ }^{* * *} p<0.001\right)$. For $\mathbf{b}$ all samples, fixed factors included developmental stage, temperature treatment, and $p \mathrm{CO}_{2}$ treatment. The interactions of the three fixed factors have been consolidated into a single, "Interactions" pie chart segment for figure simplicity. For $\mathbf{d}$ the gastrula stage and $\mathbf{f}$ the prism stage, fixed factors only included temperature and $p \mathrm{CO}_{2}$ treatment

Temperature and $p \mathrm{CO}_{2}$ affected gastrula gene expression Separate PCA plots were generated for the gastrula and prism stages. At the gastrula stage, we generally observed that both temperature and $p \mathrm{CO}_{2}$ treatments appeared to drive differences in gene expression patterns across samples. A PCA of only the gastrula stage showed that replicate samples grouped together (Fig. 1c). Here, PC1 captured $23.8 \%$ of the variance and was found to have a highly significant negative correlation to the temperature treatment (Fig. 2a). PC2 captured $12.0 \%$ of the variance (Fig. 1c) and was found to have a significant positive correlation with the $p \mathrm{CO}_{2}$ treatment (Fig. 2a). Using average embryo length measurements from this experiment (previously reported in [46]), both PC1 and PC2 were also found to be negatively correlated with gastrula body size (Fig. 2a).

Upon examining the PC loadings for the gastrula stage using the PCAtools package [50], the genes most 


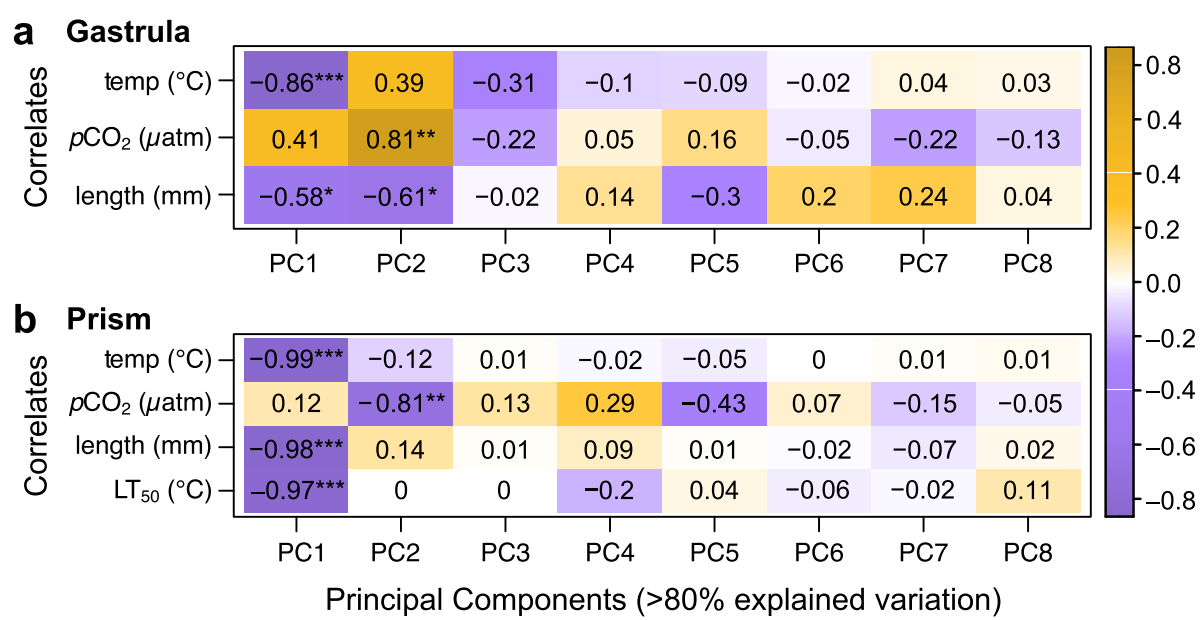

Fig. 2 Correlations at $\mathbf{a}$ the gastrula stage and $\mathbf{b}$ the prism stage between PC1-PC8 (columns), which contribute $>80 \%$ of the explained variation in gene expression, and metadata variables (rows) of the experiment treatments (i.e., temperature and $p \mathrm{CO}_{2}$ ), body size (i.e. embryo length in $\mathrm{mm}$ ), and thermotolerance (i.e. $\mathrm{LT}_{50}$ in ${ }^{\circ} \mathrm{C}$, prism stage only). The orange-purple color scale represents the strength of the Pearson's correlation (1 to -1$) .{ }^{*} p<0.05,{ }^{* *} p<0.01$, and ${ }^{* * *} p<0.001$

responsible for variation along $\mathrm{PC} 1$ included an elongation factor 1-alpha gene and a transcription factor SUM-1-like gene (Additional file 3). Genes contributing variation to $\mathrm{PC} 2$ included a poly(A)-specific ribonuclease PARN gene and a putative DNA polymerase gene. A rank-based gene ontology (GO) analysis was performed following the GO_MWU package [51] in R. Using complete sets of loading values calculated from the PCA (Additional file 3), this analysis identified GO categories enriched by genes contributing variance to the PCs. GO terms related to regulation of gene expression, ion binding, and DNA recombination were enriched by variable genes in PC1 (Additional file 4a). Genes contributing variation to $\mathrm{PC} 2$ enriched $\mathrm{GO}$ categories associated with heat shock protein binding, peptide metabolic process, and amide biosynthetic process (Additional file $4 \mathrm{~b}$ ).

A permutational multivariate ANOVA revealed that at the gastrula stage, $20.3 \%$ of the variance was explained by temperature treatment $(p=0.001)$ (Fig. 1d). Differential expression (DE) analyses conducted in limma [52] identified differentially expressed genes (relatively upand down-regulated) between gastrula raised under different temperature treatments. A total of 2049 genes were significantly up-regulated in embryos raised at $17{ }^{\circ} \mathrm{C}$ relative to embryos raised at $13^{\circ} \mathrm{C}$ (adjusted $p<$ 0.05) (Fig. 3a). These up-regulated genes included a transcription factor SUM-1-like gene ( $\log _{2}$ fold change $(\mathrm{FC})=3.39$, adj. $p=0.002$ ), a transmembrane protein 179B-like gene $\left(\log _{2} \mathrm{FC}=2.85\right.$, adj. $\left.p<0.001\right)$, a cell death protein 3 gene $\left(\log _{2} \mathrm{FC}=1.58\right.$, adj. $\left.p=0.031\right)$, and a heat shock $70 \mathrm{kDa}$ protein $12 \mathrm{~A}$-like gene $\left(\log _{2} \mathrm{FC}=\right.$ 0.661 , adj. $p=0.023$ ) (Additional file 3).

Following DE analysis, gene ontology (GO) analyses were performed using the GO_MWU package [51] to identify GO categories that were enriched by upregulated or down-regulated genes. Terms across molecular function (MF), biological process (BP), and cellular component (CC) GO categories were identified using moderated $\mathrm{t}$-test values from the full list of genes (i.e., not exclusively $\mathrm{DE}$ genes with adjusted $p<0.05$ ). GO categories significantly enriched with up-regulated genes influenced by temperature included DNA recombination, DNA metabolic process, cation channel, and G protein-coupled receptor signaling pathway (Fig. 4a, Additional file 5a).

A total of 1955 genes were down-regulated in embryos raised at $17^{\circ} \mathrm{C}$ relative to embryos raised at $13^{\circ} \mathrm{C}$ (Fig. 3a). These included a NF-kappa-B inhibitor-like protein 1 gene $\left(\log _{2} \mathrm{FC}=-2.06\right.$, adj. $\left.p<0.001\right)$, a heat shock $70 \mathrm{kDa}$ protein cognate 5 gene $\left(\log _{2} \mathrm{FC}=-0.27\right.$, adj. $\left.p=0.019\right)$, and a heat shock $70 \mathrm{kDa}$ protein 14 gene $\left(\log _{2} \mathrm{FC}=-0.40\right.$, adj. $p=0.003$ ) (Additional file 3). GO categories enriched with down-regulated genes included regulation of gene expression, chromatin organization, histone modification, and ion binding (Fig. 4a, Additional file 5a).

The $p \mathrm{CO}_{2}$ treatment also affected gene expression patterns at the gastrula stage, explaining $13.2 \%$ of the observed variance $(p=0.021)$ (Fig. $1 \mathrm{~d})$. Only 9 genes were up-regulated when comparing the $1050 \mu \mathrm{atm}$ to the $475 \mu$ atm $p \mathrm{CO}_{2}$ treatment at the gastrula stage, including a protein unc-13 homolog C-like gene ( $\log _{2}$ $\mathrm{FC}=2.54$, adj. $p=0.022$ ) (Fig. 3b, Additional file 3). GO analyses identified terms significantly enriched $(p<0.05)$ with genes affected by the $p \mathrm{CO}_{2}$ treatment. GO categories enriched with up-regulated genes included macromolecule catabolic process, ion binding, and active transmembrane transporter (Fig. 4b, Additional file 5b). A total of 166 genes were down-regulated in embryos 

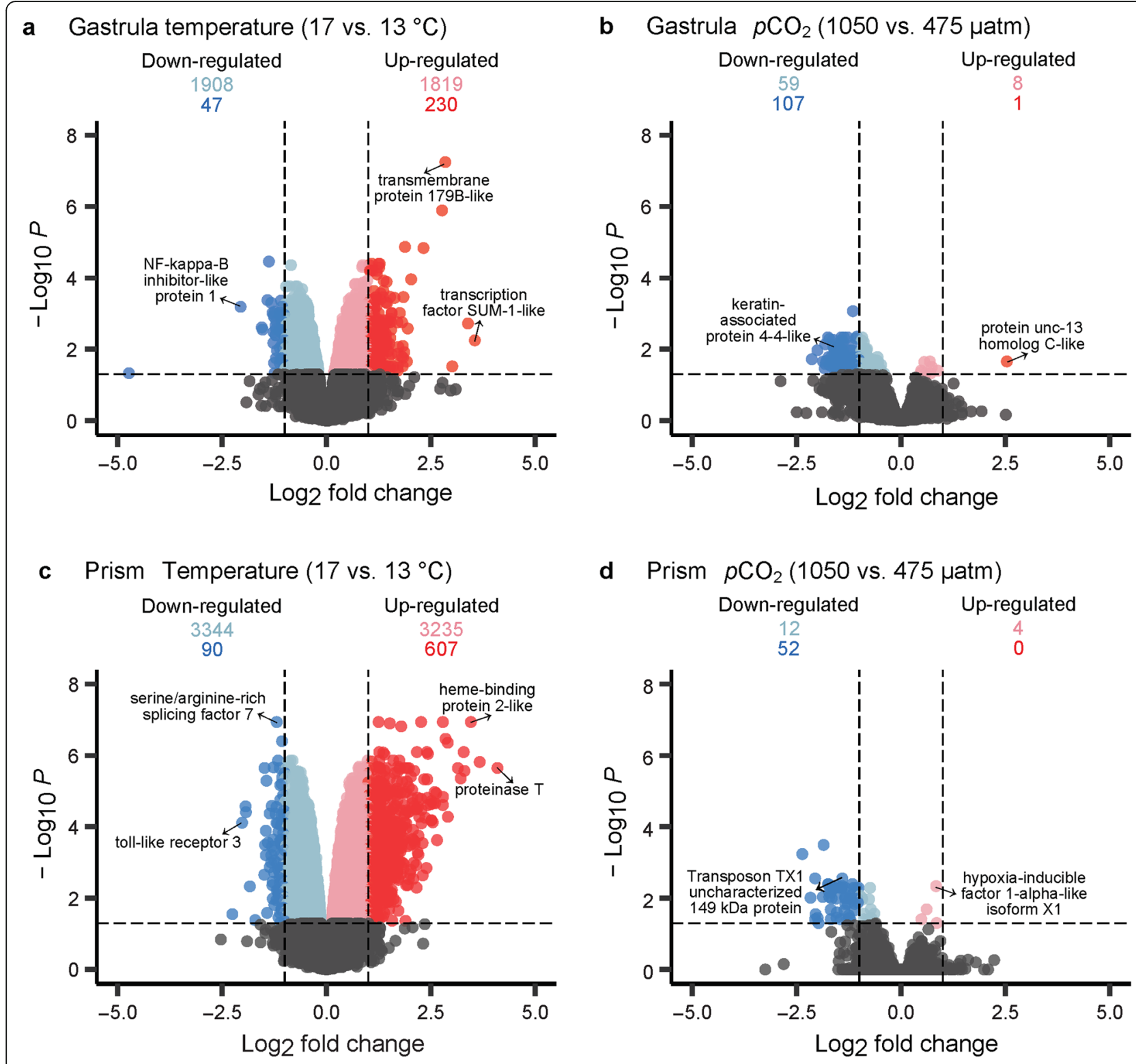

Fig. 3 Temperature, and to a lesser degree, $p \mathrm{CO}_{2}$ treatments caused differential gene expression at $\mathbf{a}, \mathbf{b}$ the gastrula stage and $\mathbf{c}, \mathbf{d}$ the prism stage of early development. Genes that were not differentially expressed are displayed in gray while significant DE genes (adjusted $p$-value $<0.05$ ) are displayed in color with a few selected genes labelled. Significant DE genes that were up-regulated are shown in pink $\left(0<\log _{2} F C<1\right)$ and red $\left(\log _{2} F C \geq 1\right)$ and significant DE genes that were down-regulated are shown in light blue $\left(-1<\log _{2} F C<0\right)$ and blue $\left(\log _{2} F C \leq-1\right)$

raised at $1050 \mu$ atm relative to embryos raised at $475 \mu$ atm (Fig. 3b), including a keratin-associated protein 4-4-like gene ( $\log _{2} \mathrm{FC}=-1.62$, adj. $\left.p=0.008\right)$ and a carbonic anhydrase 14-like isoform X3 gene $\left(\log _{2} \mathrm{FC}=-0.89\right.$, adj. $p=0.047$ ) (Additional file 3). Enriched GO categories included macromolecule biosynthetic process, macromolecule metabolic process, and nucleic acid binding (Fig. 4b, Additional file $5 \mathrm{~b}$ ). The interaction between temperature and $p \mathrm{CO}_{2}$ factors explained $7.1 \%$ of the variance observed at the gastrula stage, but the interaction was not significant $(p=0.440)$ (Fig. 1d).
Temperature was the primary factor affecting prism gene expression

Similar to the gastrula stage, the PCA of only the prism stage showed a separation of samples by treatment with sample replicates grouping together (Fig. 1e). PC1, which captured $27.6 \%$ of the variance, was found to have highly significant negative correlations to the temperature treatment, prism body size, and thermotolerance (Fig. 2b). Prism body size for each sample was estimated using average embryo length and $\mathrm{LT}_{50}$ (i.e., the temperature at which $50 \%$ mortality occurred) 


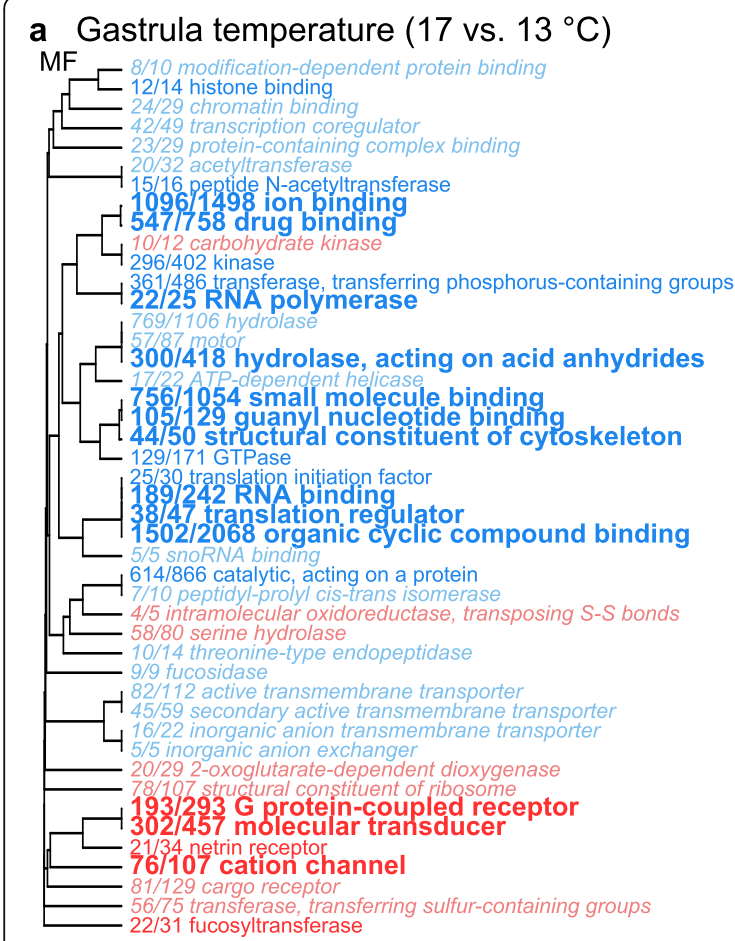

\section{b Gastrula $p \mathrm{CO}_{2}$ (1050 vs. $\left.475 \mu \mathrm{atm}\right)$}

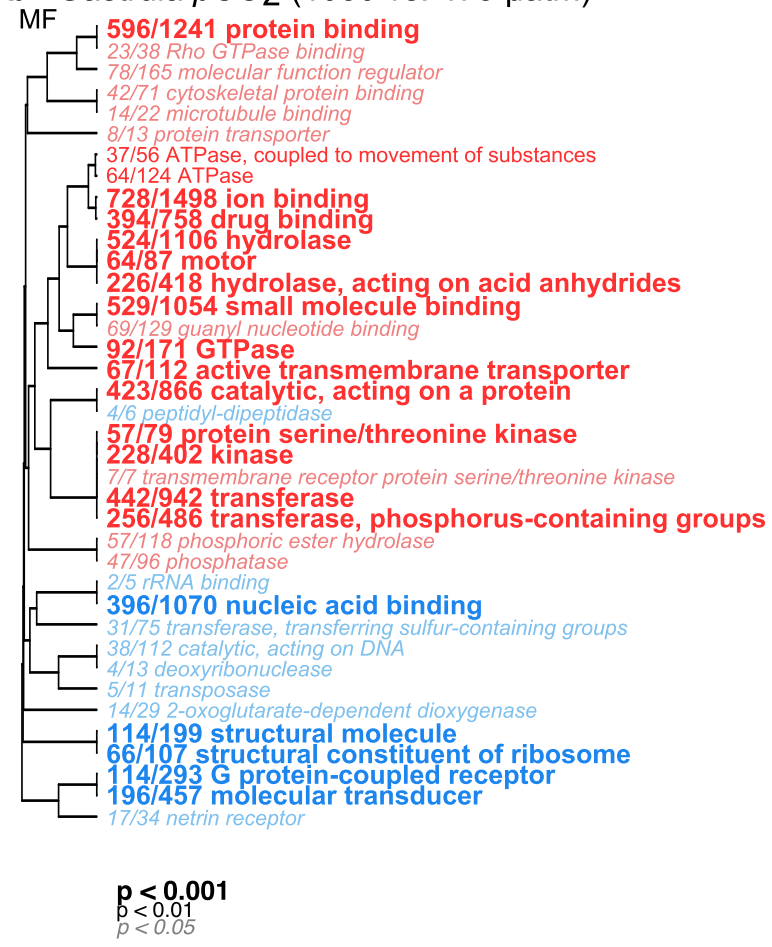

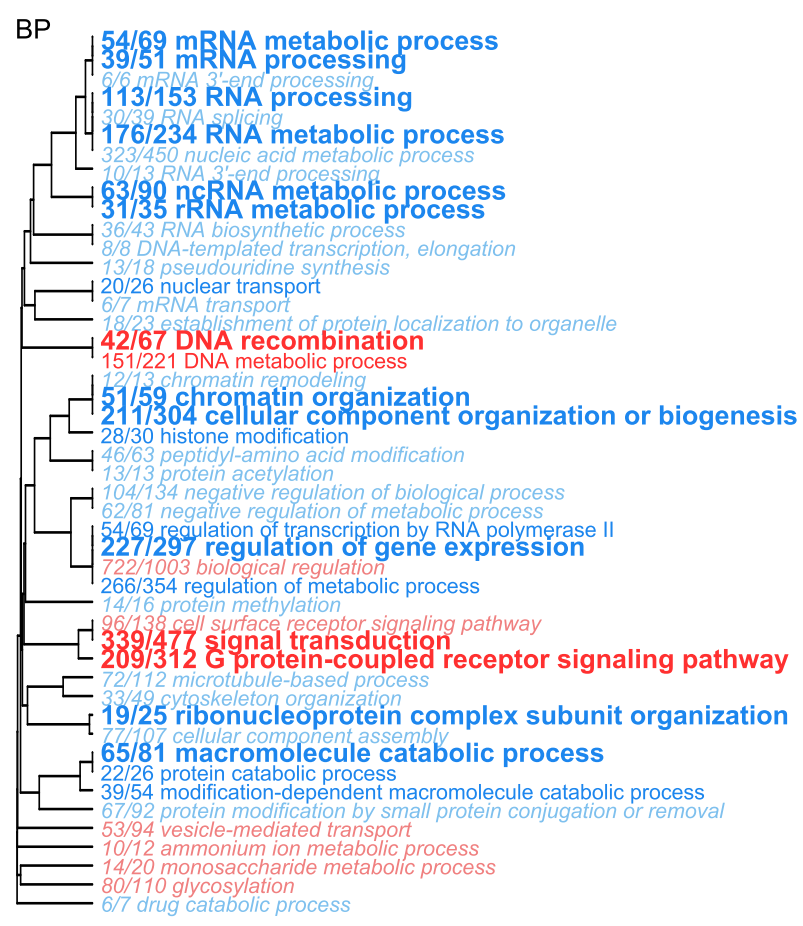
BP
254/503 localization
$90 / 172$ nitrogen compound transport
27/40 cellular macromolecule localization
$\left\{\begin{array}{l}15 / 23 \text { establishment of protein localization to organelle } \\ 97 / 192 \text { organic substance transport }\end{array}\right.$
93/175 cellular localization
$49 / 94$ vesicle-mediated transport
14/17 plasma membrane bounded cell projection organization
$16 / 21$ cell projection organization
21/33 organelle assembly
- $73 / 150$ organelle organization
62154 organele organization
$66 / 112$ microtubule-based process
$111 / 16$ enzyme linked receptor protein signaling pathway
9/10 transmembrane receptor protein serine/threonine kinase signaling pathway
$451 / 1003$ biological regulation
- 126/312 G protein-coupled receptor signaling pathway
metabolic process
59/98 phosphorylation
59/128 organonitrogen compound biosynthetic process
177/183 cellular nitrogen compound biosynthetic process
19/31 amide biosynthetic process

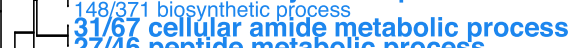
$-127 / 46$
- 51/108 macromolecule blosynthetic process
6/6 glutamine family amino acid blosynthetic process
9/13 glutamine family amino acid metabolic process
71/234 RNA metabolic process
$6 / 35$ rRNA metapolic process
$26 / 90$ ncRNA metabolic process
47153 RNA processing
235/677 cellular nitrogen compound metabolic process
1 145/450 nucleic acid metabolic process
34/81 macromolecule catabolic process
28/54 modification-dependent macromolecule catabolic process
449/1120 macromolecule metabolic process
7/9 protein polyubiquitination
$48 / 92$ protein modification by small protein conjugation or removal
$675 / 1733$ metabolic process

Fig. $4 \mathrm{GO}$ results of genes expressed at the gastrula stage. Analysis determined significant enrichment within GO categories of genes upregulated (red text) and down-regulated (blue text) due to $\mathbf{a}$ temperature and $\mathbf{b} p \mathrm{CO}_{2}$ treatments in gastrula embryos. Font sizes of the category names indicate the level of statistical significance as noted in the legend. The fraction preceding each category name is the number of genes with moderated t-statistic absolute values $>1$ relative to the total number of genes belonging to the category. GO categories of molecular function (MF) and biological process (BP) are shown 
measurements from this experiment that were previously reported in [46]. PC2 captured $9.9 \%$ of the variance (Fig. 1e) and had a significant negative correlation with the $p \mathrm{CO}_{2}$ treatment (Fig. 2b).

Loadings within PC1 showed that genes responsible for most of the variation included a heme-binding protein 2-like gene and putative tolloid-like protein 1 genes (Additional file 3). Genes contributing variance to PC2 included an elongation factor 1-alpha gene, a F-box/WD repeat-containing protein 7-like gene, and a FK506binding protein 5 -like gene (Additional file 3). Using GO_MWU and the loading values for the complete set of genes, enriched GO categories for PC1 were identified. These included GO terms related to ion transport, regulation of gene expression, methylated histone binding, RNA methyltransferase, pseudouridine synthesis, antioxidant, cellular response to DNA damage stimulus, and response to oxidative stress (Additional file 4c). Genes contributing variation to $\mathrm{PC} 2$ enriched GO categories associated with ion binding, oxidoreductase, and metabolic process (Additional file 4d).

A permutational multivariate ANOVA revealed that at the prism stage, $27.2 \%$ of the variance was explained by the temperature treatment $(p=0.001)$ (Fig. 1f). DE analysis showed a total of 3842 genes were up-regulated in embryos raised at $17^{\circ} \mathrm{C}$ relative to those raised at $13{ }^{\circ} \mathrm{C}$ (Fig. 3c). These up-regulated genes included a proteinase $\mathrm{T}$ gene $\left(\log _{2} \mathrm{FC}=4.10\right.$, adj. $\left.p<0.001\right)$, a heme-binding protein 2-like gene $\left(\log _{2} \mathrm{FC}=3.46\right.$, adj. $\left.p<0.001\right)$, a putative tolloid-like protein 1 gene $\left(\log _{2} \mathrm{FC}=3.21\right.$, adj. $p<0.001)$, and a heat shock $70 \mathrm{kDa}$ protein $12 \mathrm{~A}$-like gene $\left(\log _{2} \mathrm{FC}=0.91\right.$, adj. $\left.p<0.001\right)$ (Additional file 3 ). GO analysis identified GO categories enriched in these up-regulated genes, which included oxidoreductase, response to oxidative stress, ion transmembrane transporter, and ATP metabolic process (Fig. 5a, Additional file $5 \mathrm{c}$ ). A total of 3434 genes were down-regulated in embryos raised at $17^{\circ} \mathrm{C}$ relative to those raised at $13^{\circ} \mathrm{C}$ (Fig. 3c), including a toll-like receptor 3 gene $\left(\log _{2} \mathrm{FC}=\right.$ -2.02 , adj. $p<0.001)$, a serine/arginine-rich splicing factor 7 gene $\left(\log _{2} \mathrm{FC}=-1.19\right.$, adj. $\left.p<0.001\right)$, a heat shock $70 \mathrm{kDa}$ protein cognate 5 gene $\left(\log _{2} \mathrm{FC}=-0.21\right.$, adj. $p=$ $0.021)$, and a heat shock $70 \mathrm{kDa}$ protein 14 gene $\left(\log _{2}\right.$ $\mathrm{FC}=-0.48, p<0.001$ ) (Additional file 3). Enriched GO categories included regulation of gene expression, RNA modification, chromatin organization, cellular response to DNA damage stimulus, and metabolic process (Fig. $5 a$, Additional file $5 \mathrm{c}$ ).

The $p \mathrm{CO}_{2}$ treatment only explained $9.3 \%$ of the variance at the prism stage and was not significant $(p=$ 0.091) (Fig. 1f). In fact, only 4 genes were up-regulated when comparing the $1050 \mu \mathrm{atm}$ to the $475 \mu \mathrm{atm} p \mathrm{CO}_{2}$ treatment at the prism stage (Fig. 3d), including a hypoxia-inducible factor 1-alpha-like isoform X1 gene $\left(\log _{2} \mathrm{FC}=0.84\right.$, adj. $\left.p=0.005\right)$ (Additional file 3). GO categories enriched in up-regulated genes were related to ATPase coupled to transmembrane movement of ions, and regulation of gene expression (Fig. 5b, Additional file $5 \mathrm{~d}$ ). A total of 64 genes were down-regulated in prism embryos raised at $1050 \mu$ atm $p \mathrm{CO}_{2}$ relative to those raised at $475 \mu \mathrm{atm}$ (Fig. 3d), including a transposon TX1 uncharacterized $149 \mathrm{kDa}$ protein gene $\left(\log _{2}\right.$ $\mathrm{FC}=-1.41$, adj. $p=0.003$ ). Enriched GO terms were related to oxidoreductase and $\mathrm{G}$ protein-coupled receptor (Fig. 5b, Additional file 5d). Lastly, the interaction between temperature and $p \mathrm{CO}_{2}$ factors explained only $7.2 \%$ of the variance at the prism stage and was not significant $(p=0.362)$ (Fig. 1f).

\section{Discussion}

In this study, we examined how the gene expression patterns of $M$. franciscanus gastrula and prism embryos varied by the developmental temperature and $p \mathrm{CO}_{2}$ conditions under which they were raised. We also assessed whether the transcriptomic results aligned with the morphometric and physiological results previously reported in [46]. Although both temperature and $p \mathrm{CO}_{2}$ can influence rates of sea urchin development [34, 53], any potential differences in developmental timing should not have impacted the results of this study because samples were collected based on developmental progression to the desired embryonic stages as detailed in the Methods, rather than by hours post-fertilization. Overall, we found that while transcriptomic patterns varied by developmental stage, temperature had a dominant effect on changes in gene expression while $p \mathrm{CO}_{2}$ elicited a more subtle transcriptomic response that was largely limited to the gastrula stage. Experimental conditions impacted genes related to the cellular stress response, transmembrane transport, metabolic processes, and the regulation of gene expression.

In terms of experimental design, embryos were obtained by evenly pooling eggs from five females and fertilizing them with sperm from a single male to produce all full or half siblings. Admittedly, there are caveats to this approach. The results presented here may only be representative of a small subset of the population, or they may be driven by the quality of the particular male selected to fertilize the eggs. Upon including data from our previous study that examined gene expression patterns during $M$. franciscanus early development [48], a PCA showed that, although samples primarily grouped by developmental stage, there is a clear distinction between the embryos of the two studies (Additional file 6). This is likely due to a combination of genetic and environmental differences between the two source populations, as the adult urchins were collected from different sites and during different years. Indeed, in the purple sea 

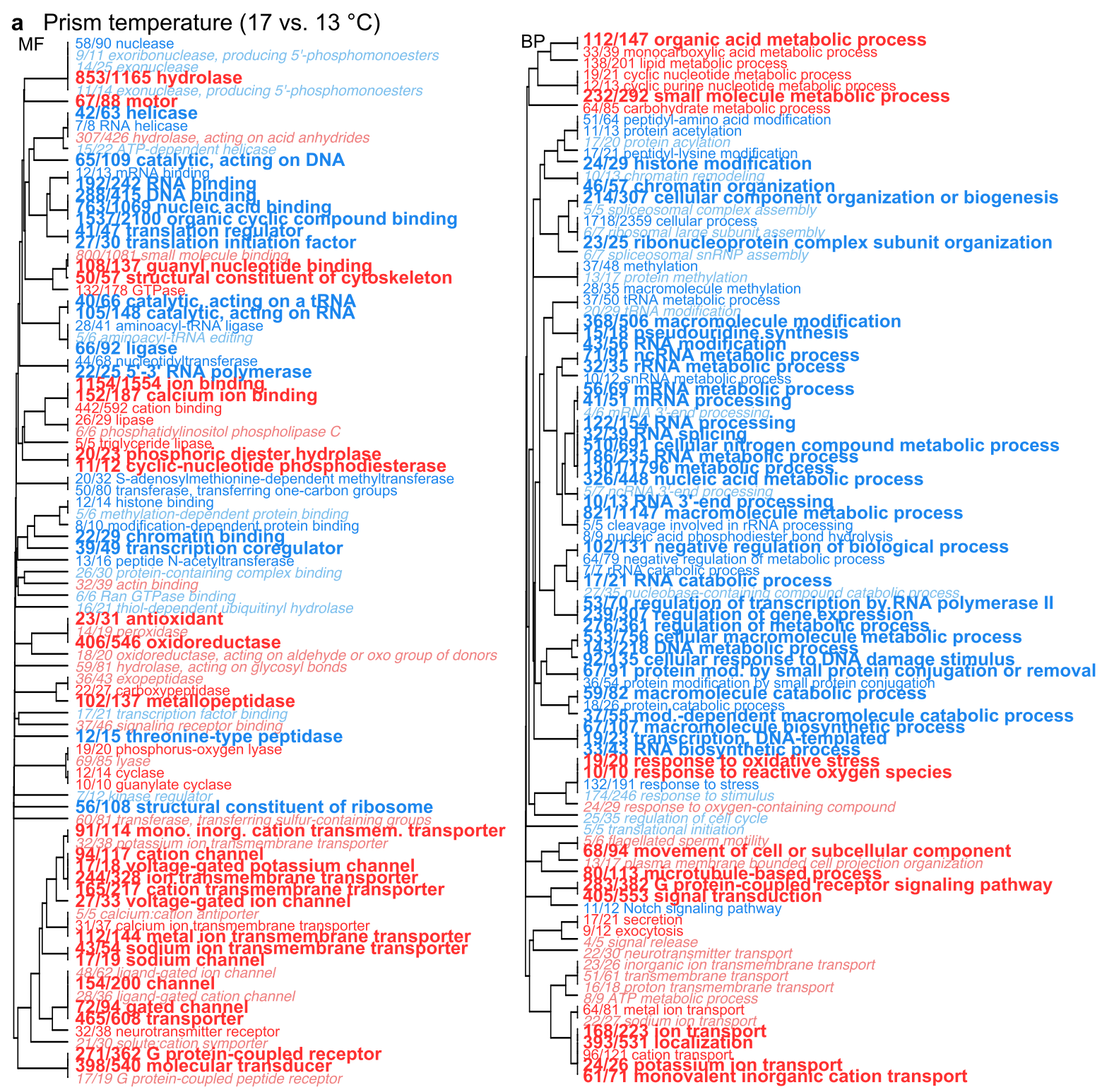

\section{b Prism pCO2 (1050 vs. $475 \mu \mathrm{atm})$}

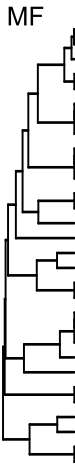

t298/1081 smallmolecule binding

$435907 \mathrm{kinase}$
1250 threonine kinase

162488 trannsterase, phosphorus-containing groups

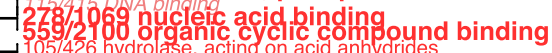

- 2188 mortor coupled. to transmemprane ion movement, phosphorylative mechanism

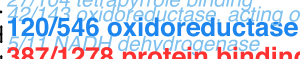

387 A 278 proterien binding

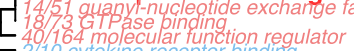

51/28 structural molefule

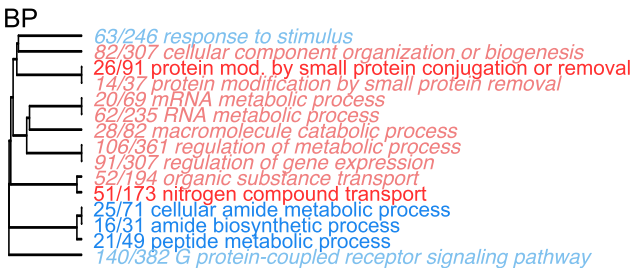

$\rightarrow 185 / 540$ molectular transied receptor
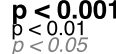

Fig. $5 \mathrm{GO}$ results of genes expressed at the prism stage. Analysis determined significant enrichment within $\mathrm{GO}$ categories of genes up-regulated (red text) and down-regulated (blue text) due to $\mathbf{a}$ temperature and $\mathbf{b} \mathrm{pCO}_{2}$ treatments in prism embryos. Font sizes of the category names indicate the level of statistical significance as noted in the legend. The fraction preceding each category name is the number of genes with moderated t-statistic absolute values $>1$ relative to the total number of genes belonging to the category. GO categories of molecular function (MF) and biological process (BP) are shown 
urchin S. purpuratus, genetic variation has been shown to influence transcriptomic responses to temperature and $p \mathrm{CO}_{2}$ stress during early development [36, 54]. Given that the data presented here represents a limited selection of the genetic variation that exists in this species, the results should be interpreted with caution. We therefore recommend that additional studies be performed within other $M$. franciscanus populations and with multiple male-female crosses to determine if our results are unique to this study. Nevertheless, this approach was implemented in an effort to limit genetic variability and male-female interactions that may have otherwise confounded the molecular results.

All samples used for RNA extractions were each composed of a pool of 5000 individuals and should thus represent the same mixture of genotypes. Therefore, we do not expect differences in gene expression patterns to be due to genetic variability between embryo cultures, particularly because a low incidence of mortality was observed during the experiment, although it was not directly measured. In the absence of selection, the observed variability in gene expression, body size, and thermotolerance between embryos raised under different experimental treatments reflect plasticity exhibited by $M$. franciscanus during its early development. We discuss this plasticity, and how it may relate to embryo performance under different conditions that $M$. franciscanus are likely to experience in their natural environments currently and in the future under ocean change scenarios.

\section{Gene expression varied by developmental stage: general patterns}

Developmental stage (gastrula or prism embryos) was the primary factor driving differences in gene expression patterns across samples (Fig. 1a and b). In a past study, we raised cultures of $M$. franciscanus embryos in a single laboratory environment that mimicked average, nonstressful conditions in situ (i.e., $15^{\circ} \mathrm{C}$ and $425 \mu$ atm $p \mathrm{CO}_{2}$ ) and documented significant transcriptomic differences between gastrula and prism stages [48]. Therefore, there are many alterations in gene expression between these stages that occur as a result of development and are independent of differences in environmental temperature and/or $p \mathrm{CO}_{2}$ conditions. This is also evident in Fig. 1a in which gastrula samples do not cluster with prism samples that share the same experimental treatment.

Because comparing gastrula versus prism gene expression patterns was not a goal of this study, no direct differential expression analyses were performed between stages, although gene expression analyses performed independently of stage (i.e., without analyzing gastrula and prism stages separately) are reported in Additional file 2. Nevertheless, embryos at each developmental stage exhibited different transcriptomic responses to temperature and $p \mathrm{CO}_{2}$ treatments. For instance, many more genes were differentially expressed due to temperature at the prism stage than at the gastrula stage (Fig. 3). Additionally, the $p \mathrm{CO}_{2}$ treatment explained a significant amount of variance in gene expression in gastrula embryos, but not later at the prism stage (Fig. 1d and f). Similarly, the morphometric response to temperature and $p \mathrm{CO}_{2}$ treatments varied by stage, in which $p \mathrm{CO}_{2}$, but not temperature, affected gastrula embryos by reducing body size under elevated $p \mathrm{CO}_{2}$ conditions (i.e., $1050 \mu \mathrm{atm}$ ) [46]. On the other hand, temperature was the dominant factor at the prism stage, with warmer conditions $\left(17^{\circ} \mathrm{C}\right)$ increasing body size, offsetting the stunting effect of high $p \mathrm{CO}_{2}$ [46]. The observed patterns between gene expression and body size will be described in greater detail later in the Discussion.

Different life stages are predicted to have different sensitivities to stress [23]. The variability between gastrula and prism stress responses may be explained by a difference in stage-specific vulnerability. During the gastrula stage, the archenteron is formed from invagination of the embryo's vegetal plate [55], a fundamental process known as gastrulation that is essential for successful development in metazoans [56]. At the prism stage, the embryo differentiates its digestive tract and develops skeletal rods, which are vital structures required for the embryos to eventually become feeding, planktotrophic larvae $[57,58]$. Accordingly, differences in responses to environmental conditions between these two stages are likely reflective of the distinct processes undergone by these embryos to ensure their continued developmental progression.

The variability between stages could also be due to the timing and duration of exposure to stress. The effects of a stressor can become increasingly deleterious as the length of exposure continues, and organisms not permitted adequate time to recover may exhibit increasingly poor performance. Furthermore, during development there may be negative carry-over effects that persist into later life stages $[59,60]$. Alternatively, organisms may acclimate to stressful conditions over time, and are therefore less adversely affected by a stressor following the initial exposure. For example, in the coral Acropora hyacinthus, the immediate transcriptomic response to heat stress was much higher than the transcriptomic response following $20 \mathrm{~h}$ of exposure to warmed conditions [61]. Thus, it remains important to acknowledge that organisms may responds differently to various environmental stressors depending on their life history as well as the timing and duration of the exposure.

\section{Temperature influenced gastrula embryos on a molecular level}

Temperature was the dominant factor influencing changes in gene expression at the gastrula stage. 
Temperature explained $20.3 \%$ of the observed variance $(p=0.001)$ with 2049 genes up-regulated and 1955 genes down-regulated in embryos raised under $17^{\circ} \mathrm{C}$ relative to those raised under $13^{\circ} \mathrm{C}$ (Figs. 1 and 3). Furthermore, $\mathrm{PC} 1$, which captured $23.8 \%$ of the gene expression variance at the gastrula stage, was significantly correlated to the temperature treatment (Fig. 2a). In general, the observed temperature effects on gene expression at the gastrula stage were approximately akin to those reported for the purple sea urchin S. purpuratus [36], whose biogeographical distribution overlaps with that of $M$. franciscanus. Here, DE analysis revealed that gastrula raised in the higher temperature treatment (i.e., $17^{\circ} \mathrm{C}$ ) expressed genes associated with a cellular stress response. Gastrula embryos of $S$. purpuratus that were raised under an $18{ }^{\circ} \mathrm{C}$ temperature treatment exhibited a comparable cellular stress response by up-regulating genes associated with cellular responses to reactive oxygen species and unfolded proteins [36]. We also found that $M$. franciscanus gastrula embryos raised under the warmer treatment exhibited transcriptomic patterns indicative of increased transmembrane transport, while embryos from the colder treatment appeared to decrease metabolic processes. Similarly, S. purpuratus increased expression of ion channel, cell-cell signaling, and metabolism genes at warmer temperatures [36]. Lastly, temperature appeared to impact the regulation of gene expression in $M$. franciscanus gastrula embryos, including genes related to epigenetic mechanisms. Temperature also appeared to influence how gene expression was regulated in S. purpuratus gastrula embryos with higher temperatures leading to a down-regulation of genes related to transcription and RNA processing [36].

Despite similarities in how temperature influenced gastrula gene expression, unlike in $M$. franciscanus, there was an effect of temperature on S. purpuratus morphology. Specifically, S. purpuratus gastrula embryos raised at warmer temperatures were significantly smaller in size [36], whereas $M$. franciscanus gastrula embryos did not significantly differ in size as a result of temperature [46]. This could reflect differences in experimental design between the studies (e.g., treatment temperatures, breeding designs, and urchin collection sites), or it could reflect differences that exist at the species level. Unlike $S$. purpuratus, the temperature response of $M$. franciscanus gastrula embryos that occurred at the molecular level was not reflected at the organismal level. We postulate that the transcriptomic differences between gastrula raised at $17^{\circ} \mathrm{C}$ and $13^{\circ} \mathrm{C}$ served to compensate for direct temperature effects and allowed the embryos to maintain the same size despite the temperature treatments. Below, we explore with greater detail how temperature affected the expression patterns of genes associated with the cellular stress response, transmembrane transport, metabolism, and gene expression regulation in $M$. franciscanus gastrula embryos.

\section{Cellular stress response (gastrula temperature)}

Response to stress at the cellular level often includes processes to mitigate or remove cell damage [62]. Cell death protein 3 , which encodes a protease involved in apoptosis [63], was up-regulated in gastrula embryos raised at $17^{\circ} \mathrm{C}$, indicating that the warmer temperature may have caused stress-induced programmed cell death. DE analysis also provided evidence of DNA damage and repair. This is similar to observations in Acropora corals in which heat stress caused an up-regulation of DNA replication and repair genes [61, 64]. Here, GO terms related to DNA metabolic process and DNA recombination were enriched with up-regulated genes under warmer temperature conditions (Fig. 4a). DNA metabolic processes can include both DNA synthesis and degradation for the purposes of replication and repair. Furthermore, DNA recombination in somatic cells has been identified as a critical mechanism for DNA damage repair $[65,66]$. Taken together, $17^{\circ} \mathrm{C}$ temperature conditions appear to induce stress within the gastrula embryos, which undergo response mechanisms to combat cellular damage.

\section{Transmembrane transport (gastrula temperature)}

Gastrula embryos raised under warmer temperatures also increased expression of genes related to transmembrane transport, potentially both within and between cells (i.e., cell-cell communication). For instance, genes related to $\mathrm{G}$ protein-coupled receptor, cation channel, cell surface receptor signaling pathway, and vesiclemediated transport were up-regulated in gastrula embryos raised under $17^{\circ} \mathrm{C}$ relative to those raised under $13^{\circ} \mathrm{C}$ (Fig. 4a). This is also supported by PC loadings, in which genes related to ion binding and cation channel contributed variance to PC1 (Additional file 4a), which was significantly correlated to the temperature treatment (Fig. 2a). Increased transport of materials, particularly ions, across cell membranes may indicate osmoregulation and maintenance of homeostasis. This aligns with reports in juvenile sea urchins of the species Loxechinus albus, in which gene expression alterations under elevated temperatures provided evidence of increased active transmembrane transport of sodium and potassium ions [67].

\section{Metabolism (gastrula temperature)}

In S. purpuratus, gastrula embryos raised under warmer temperatures up-regulated metabolic genes [36]. Here, gastrula raised under the lower temperature treatment expressed genes associated with metabolic depression. 
Specifically, GO terms identified as negative regulation of biological process and negative regulation of metabolic process were significantly enriched by genes downregulated in gastrula embryos raised under $17^{\circ} \mathrm{C}$ relative to those raised under $13{ }^{\circ} \mathrm{C}$ (Fig. 4a). In this study, metabolic rates of embryos raised under different treatments were not measured at the gastrula stage, but we may expect that, given the effect of temperature on biochemical reaction kinetics, metabolic rate should increase predictably with temperature [68]. Generally, higher metabolic rates have been recorded at warmer temperatures in marine ectotherms [69-72]. This positive correlation between temperature and metabolism has been observed in M. franciscanus at the adult stage [73].

\section{Regulation of gene expression (gastrula temperature)}

Temperature also had an evident effect on the regulation of gene expression in M. franciscanus gastrula embryos. GO terms enriched by genes relatively down-regulated in gastrula embryos raised under $17^{\circ} \mathrm{C}$ relative to those raised under $13{ }^{\circ} \mathrm{C}$ (i.e., genes were comparatively upregulated in the colder temperature treatment) were identified as regulation of transcription by RNA polymerase II, translation regulator, and regulation of gene expression (Fig. 4a). Histone binding, histone modification, chromatin remodeling, and chromatin organization genes were also associated with the $13^{\circ} \mathrm{C}$ gastrula treatment. Histone and post-translational modifications are examples of epigenetic mechanisms. These, and other epigenetic modifications can act to regulate gene function without altering the DNA sequence, promoting phenotypic plasticity and potentially modulating the response to different environmental conditions [74-76]. Histone variants and modifications may activate or repress transcription processes by altering chromatin structures, impacting the regions of the genome that are available for transcription [77], and have been shown to mediate responses to changing environmental conditions in marine organisms [78-80]. Additional analyses such as ChIP-seq (i.e., chromatin immunoprecipitation sequencing) to locate regions targeted by histone modifications and DNA-binding proteins [81, 82] or ATAC-seq (i.e., assay for transposase-accessible chromatin with high-throughput sequencing) to assess genome-wide chromatin accessibility [83] are required to profile specific histone variants or modifications and their impact on gene expression.

Although evidence of transcription regulation was observed, it is difficult to conclude if this led to an increase or decrease of gene expression, particularly with respect to the functional significance of histone modifications and chromatin remodeling. These mechanisms are much less studied in marine invertebrates than other modifications such as DNA methylation [74, 75], and although our data support that these modifications occurred in response to the environment, additional approaches are required to determine the precise modifications, their locations, and their impact on gene expression. In this study, there were more up-regulated than downregulated genes in the $17^{\circ} \mathrm{C}$ versus the $13^{\circ} \mathrm{C}$ gastrula treatment, and the up-regulated genes appeared to have a greater $\log _{2}$ FC in expression (Fig. 3a). Nevertheless, future studies pairing comparative epigenetic analyses with transcriptomic approaches are required to elucidate how these various mechanisms influence gene expression in response to different environmental conditions in M. franciscanus.

\section{$p \mathrm{CO}_{2}$ influenced gene expression of gastrula embryos}

The $p \mathrm{CO}_{2}$ treatment influenced gene expression patterns at the gastrula stage, although to a lesser degree than temperature, and the interaction between the two factors was not significant (Fig. 1d). Gastrula $p \mathrm{CO}_{2}$ conditions explained $13.2 \%$ of the observed variance $(p=$ 0.021 ) with 9 genes up-regulated and 166 genes downregulated in embryos raised under $1050 \mu$ atm $p \mathrm{CO}_{2}$ relative to those raised under $475 \mu \mathrm{atm} p \mathrm{CO}_{2}$ (Figs. 1 and 3). Additionally, PC2, which captured $12.0 \%$ of the gene expression variance at the gastrula stage, was significantly correlated to the $p \mathrm{CO}_{2}$ treatment (Fig. 2a). In this study, we anticipated that the $475 \mu \mathrm{atm} p \mathrm{CO}_{2}$ treatment was not stressful, as it represented the average ambient $p \mathrm{CO}_{2}$ levels $M$. franciscanus regularly experience in their natural habitat [44]. Evidence suggests that calcifying marine organisms such as $M$. franciscanus are sensitive to declines in ocean $\mathrm{pH}$ (i.e., increases in $p \mathrm{CO}_{2}$ levels) [84-86], and while $M$. franciscanus may periodically experience elevated $p \mathrm{CO}_{2}$ conditions in nature during upwelling events $[15,43,45,87]$, the $1050 \mu$ atm $p \mathrm{CO}_{2}$ treatment was expected to induce a stress response.

While the effect of $p \mathrm{CO}_{2}$ on gastrula gene expression patterns was less than the effect of temperature, there was a pronounced impact of $p \mathrm{CO}_{2}$ conditions on gastrula body size. Gastrula raised under elevated $p \mathrm{CO}_{2}$ conditions (i.e., $1050 \mu \mathrm{atm}$ ) were significantly smaller than those raised under $475 \mu \mathrm{atm}$ [46]. Therefore, $p \mathrm{CO}_{2}$ appeared to have a greater influence at the organismal level but elicited a relatively muted transcriptomic response compared to temperature. Below we discuss the expression patterns of genes affected by the gastrula $p \mathrm{CO}_{2}$ treatment, which included those related to metabolism and ion transport.

\section{Metabolism and ion transport (gastrula $p \mathrm{CO}_{2}$ )}

Gastrula raised under the lower $\mathrm{pCO}_{2}$ treatment (i.e., $475 \mu \mathrm{atm})$ expressed genes that significantly enriched GO terms related to several macromolecule biosynthetic processes (Fig. 4b). In contrast, those raised under the 
elevated $p \mathrm{CO}_{2}$ treatment (i.e., $1050 \mu \mathrm{atm}$ ) expressed genes that enriched GO terms associated with macromolecule catabolic processes (Fig. 4b). This may, in part, explain the difference in body size that was observed as a result of the $p \mathrm{CO}_{2}$ conditions. Gastrula in the 475 $\mu$ atm $p \mathrm{CO}_{2}$ treatment appeared to construct proteins and other macromolecules to maintain their growth and body size, while gastrula in the $1050 \mu$ atm $p \mathrm{CO}_{2}$ treatment underwent catabolic processes, possibly to obtain the energy required to respond to elevated $p \mathrm{CO}_{2}$ levels. The $p \mathrm{CO}_{2}$ stress response may include an increase of ion transport as a means of maintaining acid-base equilibrium given elevated $\mathrm{H}^{+}$concentrations under high $p \mathrm{CO}_{2}$ conditions. $\mathrm{GO}$ terms related to ion binding, active transmembrane transporter, and ATPase coupled to movement of substances were enriched by genes upregulated in gastrula raised in the $1050 \mu$ atm treatment (Fig. 4b). Similarly, increased expression of ion transport genes has been observed in gastrula embryos of $S$. purpuratus exposed to moderately elevated $p \mathrm{CO}_{2}$ levels (e.g., $\sim 800 \mu \mathrm{atm}$ ) [39], although the transcriptomic response of $S$. purpuratus embryos to $p \mathrm{CO}_{2}$ stress can be influenced by maternal effects [38].

Temperature was the dominant factor at the prism stage At the prism stage, temperature accounted for $27.2 \%$ of the observed variance $(p=0.001)$ with 3842 genes upregulated and 3434 genes down-regulated in embryos raised under $17^{\circ} \mathrm{C}$ relative to those raised under $13^{\circ} \mathrm{C}$ (Figs. 1 and 3). Furthermore, $\mathrm{PC} 1$ for the prism stage captured $27.6 \%$ of variance in gene expression and was significantly correlated to the temperature treatment (Fig. 2b). Unlike at the gastrula stage, responses to temperature that were measured at the molecular level were also observable at the organismal level. Development at the warmer $17^{\circ} \mathrm{C}$ treatment led to an increase in prism body size as well as a modest increase in prism thermotolerance [46]. Indeed, prism body size and thermotolerance variables were also highly correlated to PC1 (Fig. 2b). Therefore, the transcriptomic response to temperature appears to have influenced both growth and resistance to heat stress in $M$. franciscanus prism embryos. Prism embryos raised at $17^{\circ} \mathrm{C}$ exhibited increased expression of genes related to the cellular stress response, transmembrane transport, and metabolic processes, while genes related to DNA repair and the regulation of gene expression were associated with the colder temperature treatment (i.e., $13^{\circ} \mathrm{C}$ ).

\section{Cellular stress response (prism temperature)}

Environmental stress can lead to the production of reactive oxygen species (ROS), which can cause oxidative stress if ROS production exceeds the organism's antioxidant or damage repair capacity $[88,89]$. Oxidative stress, and the response to resulting cellular damage, due to elevated temperatures have been documented across a wide variety of taxa, including algae [90], plants [91], mollusks [92], and fishes [93, 94]. GO enrichment from the DE analysis identified terms including oxidoreductase, antioxidant, response to oxidative stress, and response to reactive oxygen species that were enriched with genes up-regulated in response to the warmer temperature treatment (Fig. 5a). At the gastrula stage, embryos in the $17^{\circ} \mathrm{C}$ treatment expressed genes associated with DNA repair, but there was no evidence of increased macromolecule repair gene expression at the prism stage. This could indicate that while both stages initiated a cellular stress response due to warmer temperatures, there was less cellular damage of nucleic acids incurred by the prism stage.

In general, global change biology research in marine systems has focused on the negative consequences of increasing temperatures associated with ocean warming [95]. However, given the expected rise in variable and extreme weather events, the impact of decreased temperatures is also an important consideration, especially in regions dominated by upwelling. DE analysis indicated that prism embryos in the $13^{\circ} \mathrm{C}$ treatment increased expression of genes related to DNA damage and repair. Specifically, identified GO terms included cellular response to DNA damage stimulus, DNA metabolic process, DNA binding, and catalytic, acting on DNA (Fig. 5a). Increased DNA damage as a result of low temperature stress has been recorded in the Pacific white shrimp Litopenaeus vannamei [96]. Although $13^{\circ} \mathrm{C}$ is within the range of temperatures that $M$. franciscanus experience in the Santa Barbara Channel (SBC) where urchins were collected for this study, it is lower than the annual average of $\sim 15^{\circ} \mathrm{C}$ [44] and may have generated stress and cellular damage in the prism embryos, leading to the activation of repair mechanisms.

\section{Transmembrane transport and metabolism (prism temperature)}

Similar to the gastrula stage, warmer temperature conditions caused an increased expression of genes related to transmembrane transport in prism embryos. Specifically, GO terms of ion binding, ion transmembrane transporter, cation channel, and sodium and potassium ion transmembrane transporters were enriched with upregulated genes (Fig. 5a), which may indicate osmoregulation and the maintenance of homeostasis. Prism embryos in the $17^{\circ} \mathrm{C}$ treatment also increased expression of genes related to energetic processes (e.g., ATP metabolic process, organic acid metabolic process, lipid metabolic process, cyclic nucleotide metabolic process, and carbohydrate metabolic process) possibly to generate the energy required to support active transmembrane 
transport of ions and other materials. The up-regulation of genes related to energy production may have also supported the increased growth of prism embryos under warmer temperatures. In contrast, DE analysis revealed an increase in expression of genes related to the negative regulation of biological and metabolic processes in prism embryos raised at $13{ }^{\circ} \mathrm{C}$. This supports the predicted expectation that organisms exhibit decreased metabolism under colder temperatures [68-72].

\section{Regulation of gene expression (prism temperature)}

At the prism stage, the colder temperature treatment exhibited an enrichment of genes related to translation regulator, transcription coregulator, regulation of gene expression, and regulation of transcription by RNA polymerase II (Fig. 5a). Additionally, GO terms identified as histone binding, chromatin organization, RNA modification, and methylation-dependent protein binding were enriched in genes down-regulated at $17^{\circ} \mathrm{C}$ relative to $13^{\circ} \mathrm{C}$ (Fig. 5a). Thus, gene expression in prism embryos raised at $13^{\circ} \mathrm{C}$ appeared to be epigenetically regulated by histone and RNA modifications. This differential expression of genes related to gene expression regulation (i.e., down-regulated at the colder temperature relative to the warmer temperature) is similar to the pattern observed at the gastrula stage.

\section{The prism stage exhibited a limited transcriptomic response to $p \mathrm{CO}_{2}$}

In other studies, echinoderms raised under elevated $p \mathrm{CO}_{2}$ conditions have exhibited altered expression of genes related to skeletogenic pathways, spicule matrix proteins, cellular stress response, ion regulation and transport, apoptosis, metabolism and ATP production $[38,39,97-100]$. Here, the $p \mathrm{CO}_{2}$ treatment had a relatively minimal effect on prism gene expression patterns. The $p \mathrm{CO}_{2}$ treatment explained only $9.3 \%$ of the observed variance at this stage and was not significant $(p=$ 0.091) (Fig. 1f). This contrasts with observations made at the organism level in which elevated $p \mathrm{CO}_{2}$ resulted in smaller prism embryos, although this could be offset by the positive effect of temperature, which acted as the dominant factor influencing body size [46]. It is interesting that the transcriptomic response to elevated $p \mathrm{CO}_{2}$ was more evident in gastrula than in prism embryos particularly because at the prism stage, skeletal rod formation occurs. Although GO terms identified as ion binding and ATPase coupled to transmembrane movement of ions were enriched with genes up-regulated at the elevated $p \mathrm{CO}_{2}$ level (Fig. $5 \mathrm{~b}$ ), we also expected to observe increased stress associated with prism embryos undergoing calcification processes under lowered $\mathrm{pH}$ conditions, but we detected no evidence of this.
It is possible that while there was a clear phenotypic difference in prism embryos raised under high versus low $p \mathrm{CO}_{2}$ conditions, the transcriptomic changes underlying this difference were much more subtle. Alternatively, the prism stage may simply lack a robust transcriptional response to the $1050 \mu$ atm $p \mathrm{CO}_{2}$ treatment. For instance, the Mediterranean sea urchin Paracentrotus lividus exhibits different transcriptomic responses depending on the magnitude of the $\mathrm{pH}$ stressor [101]. Decreased $\mathrm{pH}$ conditions caused P. lividus embryos to increase their expression of calcification genes, but not once the $\mathrm{pH}$ dropped below a certain threshold [101]. A similar result was observed in S. purpuratus in which embryos raised under a high $p \mathrm{CO}_{2}$ treatment designed to reflect near-future levels exhibited a muted transcriptomic response relative to those raised under a more moderate $p \mathrm{CO}_{2}$ treatment designed to reflect present-day low $\mathrm{pH}$ conditions [39]. The authors speculated that the transcriptional response required for acclimating to a more extreme $p \mathrm{CO}_{2}$ level was too metabolically expensive, and the embryos instead opted to conserve energy to ensure short-term survival, perhaps until environmental conditions became more favorable [39]. While a failure of embryos to respond at the transcriptomic level may permit continued successful development under high $p \mathrm{CO}_{2}$ conditions, there may be important physiological consequences such as the observed reduction in body size [46]. Thus, the lack of a transcriptomic response to high $p \mathrm{CO}_{2}$ may have important fitness consequences for $M$. franciscanus.

In the green sea urchin Strongylocentrotus droebachiensis, a quantitative genetic breeding design implemented by Runcie and colleagues demonstrated that changes in gene expression as a result of differences in $\mathrm{pH}$ exposure were minor relative to gene expression differences as a result of parentage [54]. Thus, minimal transcriptomic responses to $p \mathrm{CO}_{2}$ may be due to the genetic structure of the sea urchins used in this experiment. Furthermore, the environmental exposure history of the adult urchins may have generated non-genetic parental effects (i.e., transgenerational plasticity), which can also generate a limited transcriptomic response to high $p \mathrm{CO}_{2}$ [38]. While all embryo cultures for this experiment were composed of the same mixture of progeny from a cross between one male and five females, it is possible that the sea urchins collected for this experiment may be from a population with a relatively muted transcriptomic response to high $p \mathrm{CO}_{2}$ conditions.

It has been proposed that selection and local adaptation act on populations that are regularly exposed to high $p \mathrm{CO}_{2}$ conditions, such as those that often experience upwelling conditions within the CCS [15], and that these populations may harbor genotypes that are resistant to low $\mathrm{pH}$ conditions $[40,98,102-105]$. In $S$. 
purpuratus, transcriptomic responses to high $p \mathrm{CO}_{2}$ levels can vary by the frequency in which the sea urchin populations are exposed to upwelling conditions [40]. In particular, urchins from populations frequently exposed to low $\mathrm{pH}$ have greater transcriptomic responses to high $p \mathrm{CO}_{2}$ than those that experience low $\mathrm{pH}$ less often [40]. While the site where the adult sea urchins were collected does experience periods of low $\mathrm{pH}$ due to upwelling [43, 45], low $\mathrm{pH}$ events occur less frequently than at more northern sites within the CCS $[15,106,107]$. Therefore, the urchins used in this study may be comparatively less adapted towards mounting a transcriptomic response to high $p \mathrm{CO}_{2}$.

\section{HSP gene expression}

Heat shock proteins (HSPs) act as molecular chaperones in the cellular stress response by assisting in protein transport, protein folding and unfolding, stabilization of denatured proteins, and degradation of misfolded proteins [108, 109]. Higher levels of HSPs have been shown to confer increased thermotolerance across a variety of marine taxa [110-113]. Therefore, we may have expected an up-regulation of HSP genes linked with the slight increase in thermotolerance measured at the prism stage [46]. However, there were mixed results regarding differential expression patterns of HSP genes. At both stages, the heat shock $70 \mathrm{kDa}$ protein 12-A like gene was up-regulated in the $17^{\circ} \mathrm{C}$ treatment relative to the $13{ }^{\circ} \mathrm{C}$ treatment, whereas heat shock $70 \mathrm{kDa}$ protein cognate 5 and heat shock $70 \mathrm{kDa}$ protein 14 were down-regulated. No Hsp70 genes were differentially expressed due to $\mathrm{pCO}_{2}$, and no Hsp90 genes were differentially expressed due to temperature or $p \mathrm{CO}_{2}$.

Our results contrast with a study in $S$. purpuratus that found expression of Hsp70 and Hsp90 increased at higher temperatures [36]. However, in other investigations of sea urchin early development, increased Hsp70 expression was generally not observed under moderate warming scenarios. One study found that Hsp70 was not transcriptionally upregulated in $M$. franciscanus until larvae were exposed to temperatures at or above $20^{\circ} \mathrm{C}$ [32]. A study in S. purpuratus found induction of $\mathrm{Hsp} 70$ only occurred at temperatures above $21^{\circ} \mathrm{C}$ [37]. Therefore, the $17^{\circ} \mathrm{C}$ treatment may not have been extreme enough to induce a clear differential expression of HSP genes. Furthermore, in the green sea urchin Psammechinus miliaris, expression of HSP genes was low during early development relative to expression in adults [114]. The authors suggested that HSP expression was limited during this time [114] because over-expression of HSPs could have negative consequences for successful early development [115]. Therefore, large increases in HSP expression may be restricted during $M$. franciscanus early development.

\section{Performance under current and future ocean conditions}

Moderate ocean warming may be favorable for M. franciscanus early development by providing larger body sizes and increased thermotolerance at the prism stage [46]. The warmer temperature treatment could even mitigate the stunting effect of elevated $p \mathrm{CO}_{2}$ on prism body size [46]. This effect of warmer temperatures, however, may only be beneficial on a short-term basis. Gene expression analyses indicated that embryos raised under $17^{\circ} \mathrm{C}$ responded to cellular stress, and while there were no indications of negative impacts at the phenotypic level, there may be trade-offs and consequences to developing under warmer temperatures such as increased incidences of disease [116]. Prolonged heat exposure may eventually become detrimental, and negative carry-over effects can arise at later life stages $[59,60]$. Additionally, the observed plasticity at $17^{\circ} \mathrm{C}$ may not extend to more severe warming scenarios. For example, a study in adult $M$. franciscanus found that although mortality did not vary between urchins acclimated to $15^{\circ} \mathrm{C}$ or $18{ }^{\circ} \mathrm{C}$, mortality was significantly higher at a more extreme temperature of $21^{\circ} \mathrm{C}$ [31]. Nevertheless, our study revealed that $M$. franciscanus exhibited a sizeable transcriptomic response to $17^{\circ} \mathrm{C}$ at both developmental stages. At the urchin collection site, temperatures of $17^{\circ} \mathrm{C}$ are currently recorded during the summer months [44], and in the future, this temperature is likely to be reached more often given unmitigated climate change. More research is required to determine how $M$. franciscanus will be impacted as ocean warming continues, particularly as marine heatwaves increase in frequency $[117,118]$.

During early development, $M$. franciscanus appear to be more susceptible to rising $p \mathrm{CO}_{2}$ levels than to rising temperatures. The lack of a large transcriptional response, particularly at the prism stage, paired with a decrease in body size indicates that exposure to elevated $p \mathrm{CO}_{2}$ is detrimental to developing embryos. Continued ocean acidification is therefore likely to have adverse impacts on future $M$. franciscanus populations, although this could be offset somewhat by the positive effects of simultaneous ocean warming [46, 119-121]. However, during seasonal upwelling events, $M$. franciscanus are exposed to corrosive $\mathrm{pH}$ conditions that lack the mitigating effects of warmer temperatures $[15,16]$. Spawning that occurs during or immediately prior to an upwelling event will subject developing embryos to high $p \mathrm{CO}_{2}$ conditions paired with colder temperatures. Values equivalent to the higher $p \mathrm{CO}_{2}$ treatment (i.e., $1050 \mu \mathrm{atm} p \mathrm{CO}_{2}$ ) have been measured at the urchin collection site during upwelling events [44], so populations of $M$. franciscanus are likely already impacted by elevated $p \mathrm{CO}_{2}$. Given ocean acidification and the increase in upwelling frequency and intensity that is predicted with continued climate change [122-124], the likelihood of $M$. franciscanus developing under stressful $p \mathrm{CO}_{2}$ conditions should rise in the future. 


\section{Conclusions}

The early developmental stages of $M$. franciscanus exhibited transcriptomic plasticity under different temperature and $p \mathrm{CO}_{2}$ conditions. The extent of this plasticity, however, varied by developmental stage and by stressor. Although higher temperatures appeared to induce cellular stress, $M$. franciscanus exhibited a robust transcriptional response to temperature. The transcriptomic response to $p \mathrm{CO}_{2}$ was much more limited and may therefore increase the vulnerability of this species to ocean acidification. We caution against the overgeneralization of these findings because they represent a small portion of the genetic variability that exists in $M$. franciscanus. Future studies that examine different populations and incorporate more genetic diversity will facilitate our understanding of how this species responds to its changing environment.

Accurately predicting how organisms will respond to future ocean conditions is necessary for the implementation of effective conservation and fisheries management strategies. This study provides essential molecular-level insight towards understanding how an ecologically valuable fishery species is affected by climate change. Although we characterized the transcriptomic response of $M$. franciscanus to ecologically relevant temperature and $p \mathrm{CO}_{2}$ conditions, more work is required to determine how environmental stressors will impact the overall fitness and adaptive potential of natural populations. Detrimental impacts that occur during early development can reduce the quantity or quality of juvenile recruits. Poor recruitment will likely not be immediately evident to the $M$. franciscanus fishery until there is a marked decrease in the number of mature, harvestable adults. This delay in noticeable population declines may cause substantial alterations to coastal macroalgae ecosystems and financial losses to the fishing industry. Studies such as the one presented here are vital for developing proactive and adaptive management strategies to ensure climate-ready fisheries [42, 125].

\section{Methods}

\section{Animal collection and culturing}

Red sea urchins were collected and spawned as described in [46]. Briefly, adults were collected from Ellwood Mesa, Goleta, California, USA (34 $25.065^{\circ} \mathrm{N}$, $\left.119^{\circ} 54.092^{\prime} \mathrm{W}\right)$ at $14-\mathrm{m}$ depth via SCUBA on February 21, 2018 under California Scientific Collecting Permit SC-1223 and transported to the Marine Science Institute at the University of California Santa Barbara (UCSB). Spawning was induced by injecting $0.53 \mathrm{M} \mathrm{KCl}$ into the coelom through the perioral membrane [20]. Eggs from five individual females and sperm from a single male were collected. A subsample of eggs from each female was fertilized with sperm from the male and high fertilization success was examined for each cross (i.e., visually confirming the formation of fertilization envelopes). These subsamples were only used to verify suitable male-female compatibility and were discarded prior to the experiment. An approximately equal number of eggs from each of the five females were gently pooled together. The pool of eggs was fertilized by slowly adding dilute, activated sperm from the male until approximately $98 \%$ fertilization success was reached. Performing crosses with a single male ensured that all cultures were composed of full- or half-sibling embryos. This approach was selected in an effort to limit paternal genetic variability and differences in male-female interactions that could otherwise impact the results of the study.

As described in [46], the newly-fertilized embryos were raised in three replicate culture vessels for each of four different combined temperature and $p \mathrm{CO}_{2}$ treatments: 1) $17^{\circ} \mathrm{C}$ and $1050 \mu$ atm $\left.p \mathrm{CO}_{2}, 2\right) 17^{\circ} \mathrm{C}$ and $475 \mu \mathrm{atm}$ $\left.p \mathrm{CO}_{2}, 3\right) 13^{\circ} \mathrm{C}$ and $1050 \mu \mathrm{atm} p \mathrm{CO}_{2}$, and 4) $13^{\circ} \mathrm{C}$ and $475 \mu$ atm $p \mathrm{CO}_{2}$. These treatments represent current conditions measured in the SBC as well as projected future ocean conditions given continuing warming and acidification. It should be noted that the SBC is within a highly dynamic region in which water conditions can vary greatly. For example, the temperature recorded where and when the $M$. franciscanus were collected for this study was $13.3^{\circ} \mathrm{C}$, but throughout the year prior, the temperature at the collection site fluctuated between $10.0-20.5^{\circ} \mathrm{C}$, with an average temperature of $15.1^{\circ} \mathrm{C}$ [44]. Static treatments were selected, however, because the early development of $M$. franciscanus occurs rapidly (e.g., < 2.5 days in this study) so unlike their adult counterparts, the embryos are likely to experience relatively stable conditions. The treatment of $13{ }^{\circ} \mathrm{C}$ and $475 \mu$ atm $p \mathrm{CO}_{2}$ represents conditions that are regularly measured in the SBC [44]. $13^{\circ} \mathrm{C}$ is on the lower end of the range of temperatures observed in this region but is regularly observed during seasonal upwelling events. During upwelling events, combinations of decreased temperatures and elevated $p \mathrm{CO}_{2}$ levels are common [15, 43, 45, 87]. These upwelling conditions are represented by the combined $13{ }^{\circ} \mathrm{C}$ and $1050 \mu$ atm $p \mathrm{CO}_{2}$ treatment. Water conditions in this area also currently reach elevated temperatures of $17^{\circ} \mathrm{C}$ on occasion [44], but as ocean warming continues, these conditions are expected to increase in frequency [126]. The combined $17^{\circ} \mathrm{C}$ and 1050 uatm $p \mathrm{CO}_{2}$ treatment represents future conditions as both ocean warming and ocean acidification progress. The temperature, $\mathrm{pH}$, salinity, and total alkalinity were measured in each culture vessel daily as detailed in [46].

\section{Sample generation and sequencing}

The early gastrula stage was designated by the formation of secondary mesenchyme cells and the extension of the 
archenteron to approximately one-half the embryo's body length $\left(\sim 23.5 \mathrm{~h}\right.$ post-fertilization (hpf) at $17^{\circ} \mathrm{C}$ and $\sim 32.5 \mathrm{hpf}$ at $13^{\circ} \mathrm{C}$ ). The prism stage was designated by the tripartitioning of the archenteron, the formation of skeletal rods, and the pyramid-like body shape of the embryo ( 44 hpf at $17^{\circ} \mathrm{C}$ and $\sim 55.5 \mathrm{hpf}$ at $\left.13^{\circ} \mathrm{C}\right)$. Embryos at both developmental stages were sampled from each culture vessel by gently concentrating the embryos onto a submerged $35-\mu \mathrm{m}$ mesh filter and transferring them into a $15-\mathrm{mL}$ Falcon tube using a plastic transfer pipet. The concentration of embryos per $\mathrm{mL}$ of FSW was calculated by counting three aliquots of embryos so that a coefficient of variance $(\mathrm{CV})$ of less than $10 \%$ was reached. At both the gastrula and prism stages, 5000 embryos from each culture vessel were transferred into a $1.5 \mathrm{~mL}$ microcentrifuge tube. Embryos were quickly pelleted by centrifugation, excess seawater was removed, and the samples were flash frozen in liquid nitrogen. The samples were stored at $-80^{\circ} \mathrm{C}$ until RNA extractions were performed.

Total RNA extractions were performed on samples from each culture vessel at both the gastrula and prism stages for a total of 24 RNA extractions. RNA extractions were performed by adding $500 \mu \mathrm{L}$ of Trizol $^{\circ}$ reagent (Invitrogen) to each sample and passing the entire contents through needles of decreasing sizes (i.e., three passes through a 21-gauge needle, a 23-gauge needle, and then a 25-gauge needle) until homogenized. The RNA was isolated using a chloroform addition. The RNA was precipitated in 100\% isopropyl alcohol, washed in ice cold $80 \%$ ethanol, and resuspended in DEPCtreated water. RNA purity, quantity, and quality were verified using a NanoDrop ${ }^{\circ}$ ND100, a Qubit $^{\circ}$ fluorometer, and a TapeStation 2200 system (Agilent Technologies). The RNA samples were submitted to the Genome Center at the University of California, Davis where 24 libraries were generated using poly(A) enrichment. The 24 libraries were pooled and sequenced across two lanes on an Illumina HiSeq 4000 with 100 base-pair (bp) single reads.

\section{Data processing}

Adapter sequence contamination and base pairs with quality scores below 30 were removed from the raw sequence data using Trim Galore! (version 0.4.1) [127]. FastQC (version 0.11.5) [47] was used to verify sequence quality. The trimmed sequence data were mapped onto a developmental transcriptome for M. franciscanus [48] and expression values were calculated using RSEM (version 1.3.0) [49] and bowtie2 (version 2.3.2) [128]. The limma package [52] in $\mathrm{R}$ (version 3.4.4) was used to filter the sequence data to those that had at least 0.5 counts per million mapped reads across at least three of the samples. A scale normalization was applied to the read counts using a trimmed mean of M-values (TMM) normalization method [129]. The counts were converted to $\log$-counts per million ( $\log \mathrm{CPM})$ using the cpm function in edgeR $[130,131]$.

\section{Principal Component Analysis (PCA)}

Principal component analyses (PCAs) were performed on $\log \mathrm{CPM}$ data to examine distances between the samples using the PCAtools package [50] in R. Because gene expression patterns in $M$. franciscanus vary significantly by developmental stage [48] and because comparing gene expression patterns across development was not a goal of the current study, both principal component and differential expression analyses were executed separately for each stage. Using the eigencorplot function, PCs were correlated to metadata variables, which included the experiment treatment factors (i.e., temperature and $p \mathrm{CO}_{2}$ ). Additional metadata variables were included using data from [46]. Specifically, gastrula and prism body size were included using average length data $(\mathrm{mm})$ for each sample. Thermotolerance, which was only measured for the prism stage, was included using the average $\mathrm{LT}_{50}$ value (i.e., the temperature at which $50 \%$ mortality occurred) of each treatment. The methods of how body size and thermotolerance values were obtained are described in detail in [46]. PCAtools was used to examine the loadings of the PCs with significant correlations to metadata variables. Permutational multivariate ANOVAs were performed using the adonis function in the package vegan [132] to establish the proportion of variance explained by fixed factors (i.e., developmental stage, temperature treatment, and $p \mathrm{CO}_{2}$ treatment).

\section{Differential Expression (DE) analysis}

Differential expression (DE) analyses were performed using the limma-trend approach in limma by making pairwise comparisons between temperature treatments $\left(17^{\circ} \mathrm{C}\right.$ versus $\left.13^{\circ} \mathrm{C}\right)$ and between $p \mathrm{CO}_{2}$ treatments $(1050 \mu \mathrm{atm}$ versus $475 \mu \mathrm{atm})$ for each developmental stage. Moderated $t$-statistics and $p$-values adjusted by the Benjamini and Hochberg's method were used to control the false discovery rate [133]. Differentially expressed genes (genes relatively down- or up-regulated) were determined for each pairwise comparison of interest (adjusted $p$-value < $0.05)$. Gene ontology (GO) analyses were performed following the GO_MWU package [51] in R. This package uses a rank-based Mann-Whitney $U$ approach to determine whether GO categories are significantly enriched by up- or down-regulated genes. For each comparison, moderated t-test values for all genes were used to test GO enrichment within three categories: molecular function (MF), biological process (BP), and cellular component (CC). The reference transcriptome contains 24,900 contigs linked to GO classifications across 48,990 GO terms [48], however, improved functional annotation may increase 
the ability to detect biologically relevant information in future $M$. franciscanus RNA-seq analyses.

\section{Supplementary Information}

The online version contains supplementary material available at https://doi. org/10.1186/s12864-020-07327-x.

Additional file 1. Summary RNA-seq statistics of all samples.

Additional file 2. Differential expression analysis of all samples independent of stage (i.e., gastrula and prism stages not analyzed separately). a Principal components that contributed $>80 \%$ of the explained variation, PC1-PC7 (columns), were correlated (1 to $-1 ;{ }^{*} p<$ $0.05,{ }^{* *} p<0.01$, and $\left.{ }^{* * *} p<0.001\right)$ to metadata variables (rows) of the experiment treatments (i.e., temperature and $p \mathrm{CO}_{2}$ ). $\mathrm{GO}$ analysis determined significant enrichment within molecular function (MF), biological process (BP), and cellular component (CC) GO categories of genes that contributed variance to $\mathbf{b} P C 2, \mathbf{c} P C 3$, and $\mathbf{d} P C 4$. Font sizes of the category names indicate the level of statistical significance as noted in the legend. The fraction preceding each category name is the number of genes with loading absolute values $>0.001$ relative to the total number of genes belonging to the category. Genes were differentially expressed (displayed in color) due to $\mathbf{e}$ the temperature treatment and $\mathbf{f}$ the $\mathrm{pCO}_{2}$ treatment. $\mathrm{GO}$ analysis determined significant enrichment within $\mathrm{GO}$ categories of genes up-regulated (red text) and down-regulated (blue text) due to $\mathbf{g}$ the temperature treatment and $\mathbf{h}$ the $p \mathrm{CO}_{2}$ treatment. The fraction preceding each category name is the number of genes with moderated t-statistic absolute values $>1$ relative to the total number of genes belonging to the category.

Additional file 3. Lists of genes within each principal component that are significantly correlated to a metadata variable, and lists of genes that are significantly differentially expressed due to temperature or $p \mathrm{CO}_{2}$ experiment treatments.

Additional file 4. $\mathrm{GO}$ results of principal component (PC) loadings. The $\mathrm{GO}$ analysis determined significant enrichment within molecular function (MF), biological process (BP), and cellular component (CC) GO categories of genes that contributed variance to $\mathbf{a} \mathrm{PC} 1$ and $\mathbf{b} \mathrm{PC2}$ at the gastrula stage, as well as $\mathbf{c}$ PC1 and $\mathbf{d}$ PC2 at the prism stage. Font sizes of the category names indicate the level of statistical significance as noted in the legend. The fraction preceding each category name is the number of genes with loading absolute values $>0.001$ relative to the total number of genes belonging to the category.

Additional file 5. Additional $\mathrm{GO}$ results of differential expression (DE) analyses. The GO analysis determined significant enrichment within the cellular component (CC) category of genes up-regulated (red text) and down-regulated (blue text) due to $\mathbf{a}$ the temperature treatment in gastrula embryos, $\mathbf{b}$ the $p \mathrm{CO}_{2}$ treatment in gastrula embryos, $\mathbf{c}$ the temperature treatment in prism embryos, and $\mathbf{d}$ the $p \mathrm{CO}_{2}$ treatment in prism embryos. Font sizes of the category names indicate the level of statistical significance as noted in the legend. The fraction preceding each category name is the number of genes with moderated t-statistic absolute values $>1$ relative to the total number of genes belonging to the category.

Additional file 6. Principal component analysis (PCA) plot of all samples as well as samples from a previous study that examined gene expression patterns during the early development of M. franciscanus [48].

\section{Abbreviations}

$p \mathrm{CO}_{2}$ : Partial pressure of carbon dioxide; RNA-seq: RNA sequencing; PCA: Principal component analysis; PC: Principal component; DE: Differential expression; GO: Gene ontology; FC: Fold change; MF: Molecular function; BP: Biological process; CC: Cellular component; mm: Millimeters; ROS: Reactive oxygen species; ChIP-seq: Chromatin immunoprecipitation sequencing; ATAC-seq: Assay for transposase-accessible chromatin with highthroughput sequencing; rRNA: Ribosomal RNA; HSP: Heat shock protein; CCS: California Current System; UCSB: University of California Santa Barbara; SBC: Santa Barbara Channel; hpf: Hours post-fertilization; CV: Coefficient of variance; bp: Base-pair; TMM: Trimmed mean of M-values

\section{Acknowledgements}

We thank Christoph Pierre, Director of Marine Operations at UC Santa Barbara, for his assistance with boating and sea urchin collections. We would also like to thank Logan Kozal, Terence Leach, Maddie Housh, Jannine Chamorro, Dr. Marie Strader, and Dr. Umihiko Hoshijima for their assistance during the experiment.

\section{Authors' contributions}

JMW designed and implemented the experiment. Collection of the samples, RNA isolation, and bioinformatic analyses were performed by JMW. JMW and GEH analyzed the results and wrote the manuscript. Both authors have read and approved the final version.

\section{Funding}

This research was supported by funds from the UC Climate Champion award from the University of California to GEH. The funding source did not influence the design or execution of the study and the authors acted independently throughout the course of the research project. Animal collections were supported by resources from the Santa Barbara Coastal Long-Term Ecological Research program (NSF award OCE-1232779). During this project, JMW was supported by a U.S. National Science Foundation (NSF) Graduate Research Fellowship under Grant No. 1650114. Analytical and writing phases of the project were supported by NSF award IOS1656262 to GEH. The authors acknowledge the use of the UCSB and UCOPsupported Biological Nanostructures Laboratory within the California NanoSystems Institute. This work also used computing resources supported by NSF under grant No. ABI-1458641 to Indiana University.

\section{Availability of data and materials}

The datasets generated and/or analyzed during the current study are available in the NCBI Short Read Archive under Bioproject accession number PRJNA637102. Additional R data and analysis scripts are available at a GitHub repository (https://github.com/julietmwong27/Mfranciscanus_RNAseq_ Ranalysis).

\section{Ethics approval and consent to participate}

This study was conducted on a marine invertebrate that does not require Institutional Animal Care and Use Committee (IACUC) protocols or approval. However, the specimens were collected in accordance with the requirements of a California Scientific Collecting Permit granted to GEH (SC1223) that has been noted in the Methods. In addition, no human research subjects were used for this study, and IRB approval was not required.

\section{Consent for publication}

Not applicable.

\section{Competing interests}

The authors declare that they have no competing interests.

Received: 22 June 2020 Accepted: 14 December 2020 Published online: 07 January 2021

\section{References}

1. Ebert TA, Dixon JD, Schroeter SC, Kalvass PE, Richmond NT, WA, Woodby DA. Growth and mortality of red sea urchins Strongylocentrotus franciscanus across a latitudinal gradient. Mar Ecol Prog Ser. 1999;190:189-209.

2. Rogers-Bennett L. The ecology of Strongylocentrotus franciscanus and Strongylocentrotus purpuratus. In: Developments in Aquaculture and Fisheries Science, vol. 37; 2007. p. 393-425.

3. Leighton $D$, Jones L, North W. Ecological relationships between giant kelp and sea urchins in southern California. In: Young E, Maclachlan J, editors. Proceedings of the 5 th international seaweed symposium. Oxford, London, Edinburgh, New York, Toronto, Sydney, Paris, and Braunschweig: Pergamon Press; 1966. p. 141-53.

4. Filbee-Dexter K, Scheibling RE. Sea urchin barrens as alternative stable states of collapsed kelp ecosystems. Mar Ecol Prog Ser. 2014;495:1-25. https://doi. org/10.3354/meps 10573 .

5. Tegner MJ, Levin LA. Spiny lobsters and sea urchins: analysis of a predatorprey interaction. J Exp Mar Biol Ecol. 1983;73(2):125-50.

6. McLean JH. Sublittoral ecology of kelp beds of the open coast area near Carmel, California. Biol Bull. 1962;122(1):95-114. 
7. Estes JA, Palmisano JF. Sea otters: their role in structuring nearshore communities. Science. 1974;185(4156):1058-60.

8. Andrew N, Agatsuma Y, Ballesteros E, Bazhin A, Creaser E, Barnes D, Botsford L, Bradbury A, Campbell AK, Dixon J, et al. Status and management of world sea urchin fisheries. Oceanogr Mar Biol Annu Rev. 2002;40:343-425.

9. Keesing J, Hall K. Review of harvests and status of world sea urchin fisheries points to opportunities for aquaculture. J Shellfish Res. 1998;17(5):1597-604.

10. The Pacific Fisheries Information Network (PacFIN). https://pacfin.psmfc.org. Accessed 29 May 2020.

11. Rogers-Bennett L, Okamoto D. Mesocentrotus franciscanus and Strongylocentrotus purpuratus. In: Developments in Aquaculture and Fisheries Science, vol. 43; 2020. p. 593-608.

12. Sato KN, Powell J, Rudie D, Levin LA. Evaluating the promise and pitfalls of a potential climate change-tolerant sea urchin fishery in southern California. ICES J Mar Sci. 2018;75(3):1029-41. https://doi.org/10.1093/icesjms/fsx225.

13. Gentemann $C L$, Fewings MR, García-Reyes M. Satellite Sea surface temperatures along the West coast of the United States during the 20142016 Northeast Pacific marine heat wave. Geophys Res Lett. 2017;44:312-9. https://doi.org/10.1002/2016GL071039.

14. Oliver ECJ, Donat MG, Burrows MT, Moore PJ, Smale DA, Alexander LV, Benthuysen JA, Feng M, Gupta AS, Hobday AJ, et al. Longer and more frequent marine heatwaves over the past century. Nat Commun. 2018; 9(1324). https://doi.org/10.1038/s41467-018-03732-9.

15. Chan F, Barth JA, Blanchette C, Byrne RH, Chavez F, Cheriton O, Feely RA, Friederich G, Gaylord B, Gouhier T, et al. Persistent spatial structuring of coastal ocean acidification in the California Current System. Sci Rep. 2017; 7(2526). https://doi.org/10.1038/s41598-017-02777-y.

16. Feely R, Sabine C, Hernandez-Ayon J, lanson D, Hales B. Evidence for upwelling of corrosive "acidified" water onto the continental shelf. Science. 2008;320:1490-2.

17. Pennington JT, Chavez FP. Seasonal fluctuations of temperature, salinity, nitrate, chlorophyll and primary production at station H3/M1 over 19891996 in Monterey Bay, California. Deep Sea Res Part 2. 2000;47:947-73.

18. Bennett J, Giese AC. The annual reproductive and nutritional cycles in two western sea urchins. Mar Biol Lab. 1995;109(2):226-37.

19. Kato S, Schroeter SC. Biology of the red sea urchin, Strongylocentrotus franciscanus, and its fishery in California. Mar Fish Rev. 1985;47(3):1-20.

20. Strathmann MF. Reproduction and development of marine invertebrates of the northern Pacific coast. Seattle and London: University of Washington Press; 1987.

21. Daigle RM, Metaxas A. Vertical distribution of marine invertebrate larvae in response to thermal stratification in the laboratory. J Exp Mar Biol Ecol. 2011:409:89-98

22. Maboloc EA, Batzel G, Grünbaum D, Chan KYK. Vertical distribution of echinoid larvae in pH stratified water columns. Mar Biol. 2020;167.

23. Byrne M. Impact of ocean warming and ocean acidification on marine invertebrate life history stages: vulnerabilities and potential for persistence in a changing ocean. Oceanogr Mar Biol Annu Rev. 2011;49:1-42.

24. Dupont $\mathrm{S}$, Thorndyke $\mathrm{M}$. Impact of $\mathrm{CO}_{2}$-driven ocean acidification on invertebrates early life-history - what we know, what we need to know and what we can do. Biogeosciences. 2009;6:3109-31.

25. Gosselin L, Qian P-Y. Juvenile mortality in benthic marine invertebrates. Mar Ecol Prog Ser. 1997;146:265-82.

26. Kurihara $\mathrm{H}$. Effects of $\mathrm{CO}_{2}$-driven ocean acidification on the early developmental stages of invertebrates. Mar Ecol Prog Ser. 2008;373:275-84.

27. Byrne M. Global change ecotoxicology: identification of early life history bottlenecks in marine invertebrates, variable species responses and variable experimental approaches. Mar Environ Res. 2012;76:3-15.

28. Byrne M, Przeslawski R. Multistressor impacts of warming and acidification of the ocean on marine invertebrates' life histories. Integr Comp Biol. 2013 53(4):582-96. https://doi.org/10.1093/icb/ict049.

29. Frieder CA. Present-day nearshore $\mathrm{pH}$ differentially depresses fertilization in congeneric sea urchins. Biol Bull. 2014;226:1-7.

30. Reuter KE, Lotterhos KE, Crim RN, Thompson CA, Harley CDG. Elevated $p \mathrm{CO}_{2}$ increases sperm limitation and risk of polyspermy in the red sea urchin Strongylocentrotus franciscanus. Glob Chang Biol. 2011;17:163-71. https://doi. org/10.1111/j.1365-2486.2010.02216.x.

31. Hernández M, Bückle F, Guisado C, Barón B, Estavillo N. Critical thermal maximum and osmotic pressure of the red sea urchin Strongylocentrotus franciscanus acclimated at different temperatures. J Therm Biol. 2004;29:231-6.
32. O'Donnell M, Hammond L, Hofmann G. Predicted impact of ocean acidification on a marine invertebrate: elevated $\mathrm{CO}_{2}$ alters response to thermal stress in sea urchin larvae. Mar Biol. 2009;156:439-46.

33. Azad AK, Pearce CM, McKinley RS. Influence of stocking density and temperature on early development and survival of the purple sea urchin, Strongylocentrotus purpuratus (Stimpson, 1857). Aquac Res. 2012;43:1577-91.

34. Stumpp M, Wren J, Melzner F, Thorndyke M, Dupont S. $\mathrm{CO}_{2}$ induced seawater acidification impacts sea urchin larval development I: elevated metabolic rates decrease scope for growth and induce developmental delay. Comp Biochem Physiol A Mol Integr Physiol. 2011;160:331-40.

35. O'Donnell MJ, Todgham AE, Sewell MA, Hammond LM, Ruggiero K, Fangue NA, Zippay ML, Hofmann GE. Ocean acidification alters skeletogenesis and gene expression in larval sea urchins. Mar Ecol Prog Ser. 2010;398:157-71.

36. Runcie D, Garfield D, Babbitt C, Wygoda J, Mukherjee S, Wray G. Genetics of gene expression responses to temperature stress in a sea urchin gene network. Mol Ecol. 2012;21(18). https://doi.org/10.1111/j.1365-294X.2012.05717.x.

37. Hammond LM, Hofmann GE. Thermal tolerance of Strongylocentrotus purpuratus early life history stages: mortality, stress-induced gene expression and biogeographic patterns. Mar Biol. 2010;157:2677-87. https://doi.org/10. 1007/s00227-010-1528-z.

38. Wong JM, Johnson KM, Kelly MW, Hofmann GE. Transcriptomics reveal transgenerational effects in purple sea urchin embryos: adult acclimation to upwelling conditions alters the response of their progeny to differential $p \mathrm{CO}_{2}$ levels. Mol Ecol. 2018;27(5):1120-37. https://doi.org/10.1111/mec.14503.

39. Evans TG, Chan F, Menge BA, Hofmann GE. Transcriptomic responses to ocean acidification in larval sea urchins from a naturally variable $\mathrm{pH}$ environment. Mol Ecol. 2013;22:1609-25. https://doi.org/10.1111/mec.12188.

40. Evans TG, Pespeni MH, Hofmann GE, Palumbi SR, Sanford E. Transcriptomic responses to seawater acidification among sea urchin populations inhabiting a natural pH mosaic. Mol Ecol. 2017;26(8):2257-75. https://doi.org/10.1111/mec.14038.

41. Stumpp M, Dupont S, Thorndyke M, Melzner F. $\mathrm{CO}_{2}$ induced seawater acidification impacts sea urchin larval development II: gene expression patterns in pluteus larvae. Comp Biochem Physiol A Mol Integr Physiol. 2011;160(3):320-30.

42. Wilson JR, Lomonico S, Bradley D, Sievanen L, Dempsey T, Bell M, McAfee S, Costello C, Szuwalski C, McGonigal H, et al. Adaptive comanagement to achieve climate-ready fisheries. Conserv Lett. 2018;11:e12452. https://doi. org/10.1111/conl.12452.

43. Kapsenberg L, Hofmann GE. Ocean pH time-series and drivers of variability along the northern Channel Islands, California, USA. Limnol Oceanogr. 2016; 61:953-68. https://doi.org/10.1002/Ino.10264.

44. Reed D. SBC LTER: reef: bottom temperature: continuous water temperature, ongoing since 2000 ver 24. Environmental Data Initiative; 2020. https://doi. org/10.6073/pasta/5f8f6d12d9c8df2c26d6061bc2972599.

45. Rivest EB, O'Brien M, Kapsenberg L, Gotschalk CC, Blanchette CA, Hoshijima U, Hofmann GE. Beyond the benchtop and the benthos: dataset management planning and design for time series of ocean carbonate chemistry associated with Durafet ${ }^{\circledR}$-based pH sensors. Ecol Inform. 2016;36: 209-20. https://doi.org/10.1016/j.ecoinf.2016.08.005.

46. Wong JM, Hofmann GE. The effects of temperature and $p \mathrm{CO}_{2}$ on the size, thermal tolerance and metabolic rate of the red sea urchin (Mesocentrotus franciscanus) during early development. Mar Biol. 2020;167(33). https://doi. org/10.1007/s00227-019-3633-y.

47. Andrews S. FASTQC: a quality control tool for high throughput sequence data. 2010. Available online at: http://www.bioinformatics.babraham.ac.uk projects/fastqc.

48. Wong JM, Gaitán-Espitia JD, Hofmann GE. Transcriptional profiles of early stage red sea urchins (Mesocentrotus franciscanus) reveal differential regulation of gene expression across development. Mar Genomics. 2019; 48(100692). https://doi.org/10.1016/j.margen.2019.05.007.

49. Li B, Dewey CN. RSEM: accurate transcript quantification from RNA-Seq data with or without a reference genome. Bmc Bioinformatics. 2011;12(323).

50. Bligh K. PCAtools: everything principal components analysis. R package version 1.2.0. https://github.com/kevinblighe/PCAtools.

51. Wright RM, Aglyamova G, Meyer E, Matz MV. Gene expression associated with white syndromes in a reef-building coral, Acropora hyacinthus. BMC Genomics. 2015;16(371). https://doi.org/10.1186/s12864-015-1540-2.

52. Ritchie M, Phipson B, Wu D, Hu Y, Law C, Shi W, Smyth G. limma powers differential expression analyses for RNA-sequencing and microarray studies. Nucleic Acids Res. 2015;43(7):e47. 
53. Fujisawa $\mathrm{H}$. Differences in temperature dependence of early development of sea urchins with different growing seasons. Biol Bull. 1989;176(2):96-102.

54. Runcie D, Dorey N, Garfield D, Stumpp M, Dupont S, Wray G. Genomic characterization of the evolutionary potential of the sea urchin Strongylocentrotus droebachiensis facing ocean acidification. Genome Biol Evol. 2016;8(12):3672-84. https://doi.org/10.1093/gbe/evw272.

55. Dan K, Okazaki K. Cyto-embryological studies of sea urchins. III. Role of the secondary mesenchyme cells in the formation of the primitive gut in sea urchin larvae. Biol Bull. 1956;110(1):29-42.

56. Wolpert L. Gastrulation and the evolution of development. Development. 1992;116(Suppl):7-13.

57. Burke RD. Morphogenesis of the digestive tract of the pluteus larva of Strongylocentrotus purpuratus: shaping and bending. Int J Invertebr Repr. 1980;2(1):13-21. https://doi.org/10.1080/01651269.1980.10553338.

58. Ettensohn CA, Malinda KM. Size regulation and morphogenesis: a cellular analysis of skeletogenesis in the sea urchin embryo. Development. 1993;119: 155-67.

59. Beckerman A, Benton T, Ranta E, Kaitala V, Lundberg P. Population dynamic consequences of delayed life-history effects. Trends Ecol Evol. 2002;17(6): 263-9.

60. Hettinger A, Sanford E, Hill TM, Russell AD, Sato KN, Hoey J, Forsch M, Page HN, Gaylord B. Persistent carry-over effects of planktonic exposure to ocean acidification in the Olympia oyster. Ecology. 2012;93:2758-68.

61. Seneca FO, Palumbi S. The role of transcriptome resilience in resistance of corals to bleaching. Mol Ecol. 2015;24:1467-84.

62. Fulda S, Gorman AM, Hori O, Samali A. Cellular stress responses: cell survival and cell death. Int J Cell Biol. 2010;2010. https://doi.org/10.1155/2010/214074.

63. Xue D, Shaham S, Horvitz HR. The Caenorhabditis elegans cell-death protein CED-3 is a cysteine protease with substrate specificities similar to those of the human CPP32 protease. Genes Dev. 1996;10:1073-83. https://doi.org/10. 1101/gad.10.9.1073.

64. DeSalvo MK, Sunagawa S, Voolstra CR, Medina M. Transcriptomic responses to heat stress and bleaching in the Elkhorn coral Acropora palmata. Mar Ecol Prog Ser. 2010;402:97-113.

65. Li X, Heyer W-D. Homologous recombination in DNA repair and DNA damage tolerance. Cell Res. 2008;18:99-113.

66. Siudeja K, Bardin AJ. Somatic recombination in adult tissues: what is there to learn? Fly. 2017;11(2):121-8. https://doi.org/10.1080/19336934.2016. 1249073.

67. Vergara-Amado J, Silva AX, Manzi C, Nespolo RF, Cárdenas L. Differential expression of stress candidate genes for thermal tolerance in the sea urchin Loxechinus albus. J Therm Biol. 2017;68:104-9.

68. Gillooly JF, Brown JH, West GB, Savage VM, Charnov EL. Effects of size and temperature on metabolic rate. Science. 2001;293(5538):2248-51. https://doi. org/10.1126/science.1061967.

69. Arnberg M, Calosi P, Spicer J, Tandberg A, Nilsen M, Westerlund S, Bechmann R. Elevated temperature elicits greater effects than decreased $\mathrm{pH}$ on the development, feeding and metabolism of northern shrimp (Pandalus borealis) larvae. Mar Biol. 2013;160:2037-48. https://doi.org/10.1007/s00227-012-2072-9.

70. Manríquez PH, Torres R, Matson PG, Lee MR, Jara ME, Seguel ME, Sepúlveda $F$, Pereira L. Effects of ocean warming and acidification on the early benthic ontogeny of an ecologically and economically important echinoderm. Mar Ecol Prog Ser. 2017;563:169-84. https://doi.org/10.3354/meps11973.

71. McElroy DJ, Nguyen HD, Byrne M. Respiratory response of the intertidal seastar Parvulastra exigua to contemporary and near-future pulses of warming and hypercapnia. J Exp Mar Biol Ecol. 2012;416-417:1-7. https:// doi.org/10.1016/j.jembe.2012.02.003.

72. Pimentel MS, Trübenbach K, Faleiro F, Boavida-Portugal J, Repolho T, Rosa R. Impact of ocean warming on the early ontogeny of cephalopods: a metabolic approach. Mar Biol. 2012;159:2051-9. https://doi.org/10.1007/ s00227-012-1991-9.

73. Ulbricht RJ, Pritchard AW. Effect of temperature on the metabolic rate of sea urchins. Biol Bull. 1972;142:178-85

74. Eirin-Lopez JM, Putnam HM. Marine environmental epigenetics. Annu Rev Mar Sci. 2019;11:7.1-7.34. https://doi.org/10.1146/annurev-marine-010318095114

75. Hofmann GE. Ecological epigenetics in marine metazoans. Front Mar Sci. 2017;4(4). https://doi.org/10.3389/fmars.2017.00004.

76. Verhoeven KJ, Vonholdt BM, Sork VL. Epigenetics in ecology and evolution: what we know and what we need to know. Mol Ecol. 2016;25:1631-8. https://doi.org/10.1111/mec.13617.
77. Berger SL. The complex language of chromatin regulation during transcription. Nature. 2007;447:407-12.

78. Gonzalez-Romero R, Suarez-Ulloa V, Rodriguez-Casariego J, Garcia-Souto D, Diaz G, Smith A, Pasantes JJ, Rand G, Eirin-Lopez JM. Effects of Florida red tides on histone variant expression and DNA methylation in the eastern oyster Crassostrea virginica. Aquat Toxicol. 2017;186:196-204.

79. Rodriguez-Casariego JA, Ladd MC, Shantz AA, Lopes C, Cheema MS, Kim B, Roberts SB, Fourqurean JW, Ausio J, Burkepile DE, et al. Coral epigenetic responses to nutrient stress: histone H2A.X phosphorylation dynamics and DNA methylation in the staghorn coral Acropora cervicornis. Ecol Evol. 2018; 8(23):12193-207.

80. Veluchamy A, Rastogi A, Lin X, Lombard B, Murik O, Thomas Y, Dingli F, Rivarola M, Ott S, Liu X, et al. An integrative analysis of post-translational histone modifications in the marine diatom Phaeodactylum tricornutum. Genome Biol. 2015;16(102). https://doi.org/10.1186/s13059-015-0671-8.

81. Park PJ. ChIP-seq: advantages and challenges of a maturing technology. Nat Rev Genet. 2009;10:669-80

82. O'Geen H, Echipare L, Farnham PJ. Using ChIP-Seq technology to generate high-resolution profiles of histone modifications. In: Tollefsbol T, editor. Epigenetics Protocols, vol. 791. Totowa: Humana Press; 2011. p. 265-86.

83. Buenrostro JD, Wu B, Chang HY, Greenleaf WJ. ATAC-seq: A method for assaying chromatin accessibility genome-wide. Curr Protoc Mol Biol. 2015; 109:21.29.21-9. https://doi.org/10.1002/0471142727.mb2129s109.

84. Doney SC, Fabry VJ, Feely RA, Kleypas JA. Ocean acidification: the other $\mathrm{CO}_{2}$ problem. Annu Rev Mar Sci. 2009;1:169-92. https://doi.org/10.1146/annurev. marine.010908.163834.

85. Hofmann GE, Barry JP, Edmunds PJ, Gates RD, Hutchins DA, Klinger T, Sewell MA. The effect of ocean acidification on calcifying organisms in marine ecosystems: an organism-to-ecosystem perspective. Annu Rev Ecol Evol Syst. 2010;41:127-47.

86. Kroeker K, Kordas R, Crim R, Singh G. Meta-analysis reveals negative yet variable effects of ocean acidification on marine organisms. Ecol Lett. 2010; 13:1419-34

87. Hofmann G, Washburn L, SBC LTER. Ocean: time-series: mid-water SeaFET and $\mathrm{CO} 2$ system chemistry at Mohawk reef (MKO), ongoing since 2012-0111: Santa Barbara Coastal LTER; 2015. Environmental Data Initiative. https:// doi.org/10.6073/pasta/826b170f29458104621aa9f0e36c8901.

88. Ahmed RG. Is there a balance between oxidative stress and antioxidant defense system during develoopment? Med J Islamic World Acad Sci. 2005; 15(2):55-63.

89. Costantini D. Oxidative stress in ecology and evolution: lessons from avian studies. Ecol Lett. 2008;11:1238-51. https://doi.org/10.1111/j.1461-0248.2008. 01246.x.

90. Lesser MP. Elevated temperatures and ultraviolet radiation cause oxidative stress and inhibit photosynthesis in symbiotic dinoflagellates. Limnol Oceanogr. 1996:41(2):271-83.

91. Ali MB, Hahn E-J, Paek K-Y. Effects of temperature on oxidative stress defense systems, lipid peroxidation and lipoxygenase activity in Phalaenopsis. Plant Physiol Biochem. 2005;43:213-23. https://doi.org/10. 1016/j.plaphy.2005.01.007.

92. Verlecar XN, Jena KB, Chainy GBN. Biochemical markers of oxidative stress in Perna viridis exposed to mercury and temperature. Chem Biol. 2007;167: 219-26. https://doi.org/10.1016/j.cbi.2007.01.018.

93. Madeira D, Narciso L, Cabral HN, Vinagre C, Diniz MS. Influence of temperature in thermal and oxidative stress responses in estuarine fish. Comp Biochem Physiol A Mol Integr Physiol. 2013;116:237-43. https://doi. org/10.1016/j.cbpa.2013.06.008.

94. Lushchak VI, Bagnyukova TV. Temperature increase results in oxidative stress in goldfish tissues. 2. Antioxidant and associated enzymes. Comp Biochem Physiol C. 2006;143:36-41. https://doi.org/10.1016/j.cbpc.2005.11.018.

95. Wernberg T, Smale DA, Thomsen MS. A decade of climate change experiments on marine organisms: procedures, patterns and problems. Glob Chang Biol. 2012;18:1491-8. https://doi.org/10.1111/j.1365-2486. 2012.02656.x.

96. Qiu J, Wang W-N, Wang L-J, Liu Y-F, Wang A-L. Oxidative stress, DNA damage and osmolality in the Pacific white shrimp, Litopenaeus vannamei exposed to acute low temperature stress. Comp Biochem Physiol C. 2011; 154:36-41.

97. Evans TG, Watson-Wynn P. Effects of seawater acidification on gene expression: resolving broader-scale trends in sea urchins. Biol Bull. 2014; 226(3):237-54 
98. Padilla-Gamiño J, Kelly M, Evans T, Hofmann G. Temperature and $\mathrm{CO}_{2}$ additively regulate physiology, morphology and genomic responses of larval sea urchins, Strongylocentrotus purpuratus. Proc R Soc B. 2013;280. https://doi.org/10.1098/rspb.2013.0155.

99. Stumpp M, Hu MY, Melzner F, Gutowska MA, Dorey N, Himmerkus N, Holtmann WC, Dupont ST, Thorndyke MC, Bleich M. Acidified seawater impacts sea urchin larvae $\mathrm{pH}$ regulatory systems relevant for calcification. PNAS. 2012;109(44):18192-7.

100. Todgham A, Hofmann G. Transcriptomic response of sea urchin larvae Strongylocentrotus purpuratus to $\mathrm{CO}_{2}$-driven seawater acidification. J Exp Biol. 2009;212:2579-94. https://doi.org/10.1242/jeb.032540.

101. Martin S, Richier S, Pedrotti M-L, Dupont S, Castejon C, Gerakis Y, Kerros M-E, Oberhänsli F, Teyssié J-L, Jeffree $R$, et al. Early development and molecular plasticity in the Mediterranean Sea urchin Paracentrotus lividus exposed to $\mathrm{CO}_{2}$-driven acidification. J Exp Biol. 2011;214:1357-68. https://doi.org/10. 1242/jeb.051169

102. Kelly MW, Padilla-Gamiño JL, Hofmann GE. Natural variation and the capacity to adapt to ocean acidification in the keystone sea urchin Strongylocentrotus purpuratus. Glob Chang Biol. 2013;19:2536-46. https://doi. org/10.1111/gcb.12251.

103. Pespeni M, Chan F, Menge B, Palumbi S. Signs of adaptation to local pH conditions across an environmental mosaic in the California current ecosystem. Integr Comp Biol. 2013;53(5):857-70.

104. Pespeni M, Sanford E, Gaylord B, Hill T, Hosfelt J, Jaris H, LaVigne M, Lenz E, Russell $A$, Young $M$, et al. Evolutionary change during experimental ocean acidification. PNAS. 2013;110(17):6937-24.

105. Kapsenberg L, Okamoto D, Dutton J, Hofmann G. Sensitivity of sea urchin fertilization to $\mathrm{pH}$ varies across a natural pH mosaic. Ecol Evol. 2017;7:173750. https://doi.org/10.1002/ece3.2776.

106. Kroeker K, Sanford E, Rose J, Blanchette C, Chan F, Chavez F, Gaylord B, Helmuth B, Hill T, Hofmann $G$, et al. Interacting environmental mosaics drive geographic variation in mussel performance and predation vulnerability. Ecol Lett. 2016;19:771-9. https://doi.org/10.1111/ele.12613.

107. Hofmann G, Evans T, Kelly M, Padilla-Gamiño J, Blanchette C, Washburn L, Chan F, McManus M, Menge B, Gaylord B, et al. Exploring local adaptation and the ocean acidification seascape - studies in the California current large marine ecosystem. Biogeosciences. 2014;11:1-13.

108. Lindquist S. The heat-shock response. Annu Rev Biochem. 1986;55:1151-91.

109. Sørensen JG, Kristensen TN, Loeschcke V. The evolutionary and ecological role of heat shock proteins. Ecol Lett. 2003;6:1025-37. https://doi.org/10. 1046/j.1461-0248.2003.00528.x.

110. Sorte CJB, Hofmann GE. Thermotolerance and heat-shock protein expression in northeastern Pacific Nucella species with different biogeographical ranges. Mar Biol. 2005;146:985-93. https://doi.org/10.1007/ s00227-004-1508-2.

111. Clegg JS, Uhlnger KR, Jackson SA, Cherr GN, Rifkin E, Friedman CS. Induced thermotolerance and the heat shock protein-70 family in the Pacific oyster Crassostrea gigas. Mol Mar Biol Biotechnol. 1998;7(1):21-30.

112. Brun NT, Bricelj VM, MacRae TH, Ross NW. Acquisition of thermotolerance in bay scallops, Argopecten irradians irradians, via differential induction of heat shock proteins. J Exp Mar Biol Ecol. 2009;371:77-83.

113. Dong Y, Dong S. Induced thermotolerance and expression of heat shock protein 70 in sea cucumber Apostichopus japonicus. Fish Sci. 2008;74:573-8.

114. Clark MS, Suckling CC, Cavallo A, Mackenzie CL, Thorne MAS, Davies AJ, Peck LS. Molecular mechanisms underpinning transgenerational plasticity in the green sea urchin Psammechinus miliaris. Sci Rep. 2019;9.

115. Krebs RA, Feder ME. Hsp70 and larval thermotolerance in Drosophila melanogaster: how much is enough and when is more too much? J Insect Physiol. 1998;44:1091-101.

116. Lester SE, Tobin ED, Behrens MD. Disease dynamics and the potential role of thermal stress in the sea urchin, Strongylocentrotus purpuratus. Can J Fish Aquat Sci. 2007;64(2):314-23. https://doi.org/10.1139/f07-010.

117. Frölicher TL, Laufkötter C. Emerging risks from marine heat waves. Nat Commun. 2018;9(650). https://doi.org/10.1038/s41467-018-03163-6.

118. Ummenhofer CC, Meehl GA. Extreme weather and climate events with ecological relevance: a review. Philos T R Soc B. 2017;372:20160135. https:// doi.org/10.1098/rstb.2016.0135.

119. Byrne M, Foo SA, Soars NA, Wolfe KDL, Nguyen HD, Hardy N, Dworjanyn SA. Ocean warming will mitigate the effects of acidification on calcifying sea urchin larvae (Heliocidaris tuberculata) from the Australian global warming hot spot. J Exp Mar Biol Ecol. 2013;448:250-7. https://doi.org/10.1016/j. jembe.2013.07.016.

120. Byrne M, Lamare M, Winter D, Dworjanyn SA, Uthicke $S$. The stunting effect of a high $\mathrm{CO}_{2}$ ocean on calcification and development in sea urchin larvae, a synthesis from the tropics to the poles. Philos Trans R Soc Lond Ser B Biol Sci. 2013;368(1627). https://doi.org/10.1098/rstb.2012.0439.

121. Sheppard Brennand H, Soars N, Dworjanyn S, Davis A, Byrne M. Impact of ocean warming and ocean acidification on larval development and calcification in the sea urchin Tripneustes gratilla. PLoS One. 2010;5(6). https://doi.org/10.1371/journal.pone.0011372.

122. Bakun A, Black BA, Bograd SJ, García-Reyes M, Miller AJ, Rykaczewski RR, Sydeman WJ. Anticipated effects of climate change on coastal upwelling ecosystems. Cur Climate Change Rep. 2015;1(2):85-93. https://doi.org/10. 1007/s40641-015-0008-4.

123. Sydeman WJ, García-Reyes M, Schoeman DS, Rykaczewski RR, Thompson SA, Black BA, Bograd SJ. Climate change and wind intensification in coastal upwelling ecosystems. Science. 2014;345(6192):77-80.

124. Snyder MA, Sloan LC, Diffenbaugh NS, Bell JL. Future climate change and upwelling in the California Current. Geophys Res Lett. 2003;30(15). https:// doi.org/10.1029/2003GL017647.

125. Caputi N, Kangas M, Denham A, Feng M, Pearce A, Hetzel Y, Chandrapavan A. Management adaptation of invertebrate fisheries to an extreme marine heat wave event at a global warming hot spot. Ecol Evol. 2016;6(11):358393. https://doi.org/10.1002/ece3.2137.

126. IPCC. Summary for Policymakers. 2019.

127. Krueger F. Trim Galore!: A wrapper tool around Cutadapt and FastQC to consistently apply quality and adapter trimming to FastQ files. Available at: www.bioinformatics.babraham.ac.uk/projects/trim_galore/. 2015.

128. Langmead B, Salzberg SL. Fast gapped-read alignment with bowtie 2. Nat Methods. 2012:9:357-9.

129. Robinson MD, Oshlack A. A scaling normalization method for differential expression analysis of RNA-seq data. Genome Biol. 2010;11:R25.

130. Robinson MD, McCarthy DJ, Smyth GK. edgeR: a bioconductor package for differential expression analysis of digital gene expression data. Bioinformatics. 2010;26(1):139-40. https://doi.org/10.1093/bioinformatics/ btp616.

131. McCarthy DJ, Chen Y, Smyth GK. Differential expression analysis of multifactor RNA-Seq experiments with respect to biological variation. Nucleic Acids Res. 2012;40(10):4288-97. https://doi.org/10.1093/nar/gks042.

132. Oksanen J, Blanchet FG, Friendly M, Kindt R, Legendre P, McGlinn D, Minchin PR, O'Hara RB, Simpson GL, Solymos P et al. vegan: Community Ecology Package. R package version 25-6. 2019.

133. Benjamini $Y$, Hochberg $Y$. Controlling the false discovery rate: a practical and powerful approach to multiple testing. J R Stat Soc B. 1995;57:289-300.

\section{Publisher's Note}

Springer Nature remains neutral with regard to jurisdictional claims in published maps and institutional affiliations.

\section{Ready to submit your research? Choose BMC and benefit from:}

- fast, convenient online submission

- thorough peer review by experienced researchers in your field

- rapid publication on acceptance

- support for research data, including large and complex data types

- gold Open Access which fosters wider collaboration and increased citations

- maximum visibility for your research: over $100 \mathrm{M}$ website views per year

At BMC, research is always in progress.

Learn more biomedcentral.com/submissions 